\title{
Immune-mediated changes in actinic keratosis following topical treatment with imiquimod $5 \%$ cream
}

\author{
Abel Torres ${ }^{1}$, Leslie Storey ${ }^{1}$, Makala Anders ${ }^{1}$, Richard L Miller ${ }^{2}$, \\ Barbara J Bulbulian², Jizhong Jin², Shalini Raghavan², James Lee ${ }^{3}$, \\ Herbert B Slade ${ }^{3}$ and Woubalem Birmachu*2
}

\author{
Address: ${ }^{1}$ Dermatology Office, Loma Linda University Medical Center, Loma Linda, California, USA, ${ }^{2}$ Pharmacology, $3 \mathrm{M}$ Pharmaceuticals, St Paul, \\ Minnesota, USA and ${ }^{3}$ Medical \& Scientific Affairs, 3M Pharmaceuticals, St Paul, Minnesota, USA \\ Email: Abel Torres - abelt@aol.com; Leslie Storey - lesliestorey13@yahoo.com; Makala Anders - makalaanders@yahoo.com; \\ Richard L Miller - rlmiller1@MMM.com; Barbara J Bulbulian - bjbulbulian@MMM.com; Jizhong Jin - jjin1@MMM.com; \\ Shalini Raghavan - sraghavan1@MMM.com; James Lee - jlee107@cntus.jnj.com; Herbert B Slade - hbslade@comcast.net; \\ Woubalem Birmachu* - wbirmachu@comcast.net \\ * Corresponding author
}

Published: 26 January 2007

Journal of Translational Medicine 2007, 5:7 doi:10.1 186/1479-5876-5-7
Received: II June 2006

Accepted: 26 January 2007

This article is available from: http://www.translational-medicine.com/content/5/I/7

(C) 2007 Torres et al; licensee BioMed Central Ltd.

This is an Open Access article distributed under the terms of the Creative Commons Attribution License (http://creativecommons.org/licenses/by/2.0), which permits unrestricted use, distribution, and reproduction in any medium, provided the original work is properly cited.

\begin{abstract}
Background: The objective of this study was to identify the molecular processes responsible for the anti-lesional activity of imiquimod in subjects with actinic keratosis using global gene expression profiling.

Methods: A double-blind, placebo-controlled, randomized study was conducted to evaluate gene expression changes in actinic keratosis treated with imiquimod $5 \%$ cream. Male subjects ( $N=17$ ) with $\geq 5$ actinic keratosis on the scalp applied placebo cream or imiquimod 3 times a week on nonconsecutive days for 4 weeks. To elucidate the molecular processes involved in actinic keratosis lesion regression by imiquimod, gene expression analysis using oligonucleotide arrays and real time reverse transcriptase polymerase chain reaction were performed on shave biopsies of lesions taken before and after treatment.

Results: Imiquimod modulated the expression of a large number of genes important in both the innate and adaptive immune response, including increased expression of interferoninducible genes with known antiviral, anti-proliferative and immune modulatory activity, as well as various Toll-like receptors. In addition, imiquimod increased the expression of genes associated with activation of macrophages, dendritic cells, cytotoxic $T$ cells, and natural killer cells, as well as activation of apoptotic pathways.

Conclusion: Data suggest that topical application of imiquimod stimulates cells in the skin to secrete cytokines and chemokines that lead to inflammatory cell influx into the lesions and subsequent apoptotic and immune cell-mediated destruction of lesions.
\end{abstract}




\section{Background}

Actinic keratosis (AK) are common, cutaneous, precancerous neoplasms appearing as rough, dry, scaly lesions that occur primarily on the sun-exposed skin of middle-aged and elderly people [1-3]. Although the exact mechanism of pathogenesis of AK development is unknown, part of the pathogenesis may involve suppression of the immune response against dysplastic cells [4]. It is believed that prolonged ultraviolet exposure changes the immune surveillance mechanism of the skin, contributing to the tolerance of tumor cells [5]. If left untreated, AK can progress to squamous cell carcinoma, a locally aggressive and occasionally metastatic tumor type [6]. Standard treatment of AK includes various types of surgical and chemical treatments $[7,8]$, which are often associated with scarring and infection, and may not address sub clinical lesions [8].

Toll-like receptors (TLR) are pattern recognition receptors that detect pathogen-associated molecular patterns (PAMPs) and play key roles in the activation of innate and adaptive immune responses [9,10]. Currently, 10 human TLRs have been identified. The natural ligands for all but TLR10 have also been identified [9]. Toll-like receptors are primarily expressed on immune cells such as monocytes, dendritic cells (DCs), and lymphocytes [11], but some TLRs are also expressed on nonimmune cells, including endothelial cells, epithelial cells, and keratinocytes [12].

The role of TLRs in the pathogenesis and treatment of dermatological diseases is increasingly recognized [13]. Imiquimod, a member of a class of drugs termed immune response modifiers has been shown to be a selective TLR7 agonist [[14,15], and unpublished internal data]. Imiquimod is the first TLR-agonist pharmaceutical product approved for human use, and is indicated for the topical treatment of external genital and perianal warts caused by human papilloma virus [16]. Recently, the approved indications have been expanded to include treatment of AK [17] and superficial basal cell carcinoma [18-20].

The antiviral and anti-tumor activity of imiquimod is believed to be due to the activation of the innate immune response, specifically activation of antigen-presenting cells such as monocytes, macrophages and plasmacytoid and myeloid DCs to induce interferon alpha (IFN $\alpha$ ) and other cytokines and chemokines $[21,15]$. Imiquimod also enhances co stimulatory molecule expression important for triggering an adaptive immune response [15]. Topical application of the drug has been shown to induce IFN $\alpha$ and interleukin 6 (IL6) in AK lesions and external genital warts $[22,23]$. Imiquimod and the chemically related immune response modifier resiquimod have also shown potent vaccine adjuvant effects in mice and man [23-27]. Even though the immune-modulatory activity of imiqui- mod is well established, the precise molecular changes responsible for the antilesional activity of topically applied imiquimod in AK is not fully understood.

The objective of this study was to explore the molecular processes responsible for the antilesional activity of imiquimod in subjects with actinic keratosis using global gene expression profiling.

\section{Methods and Materials \\ Institutional review boardlinformed consent}

This study was conducted at Loma Linda University School of Medicine/Medical Center, Department of Internal Medicine, Division of Dermatology, Loma Linda, California. The study protocol, subject informed consent documents, and subject information documents were submitted to and received approval from the study center's Institution Review Board. This study was conducted according to the Code of Federal Regulations of the United States Food and Drug Administration (21 CFR Part 56, Institutional Review Boards, and Part 50, Protection of Human Subjects) and the International Conference on Harmonization Edition 6, Guideline for Good Clinical Practice.

\section{Study Conduct}

This was a phase II, double-blind, placebo-controlled, randomized parallel group study. Randomized subjects had at least 5 clinically visible AK lesions within a $25-\mathrm{cm}^{2}$ area on the balding scalp. Subjects were randomized to imiquimod or placebo cream in a 3:1 ratio and applied study cream to the treatment area 3 times per week for 4 weeks. Study cream was applied prior to normal sleeping hours and remained on the skin for approximately 8 hours before it was removed. Safety evaluations were made at all treatment and post treatment visits, and included monitoring of adverse events and local skin reactions, as well as photographing the treatment area and reviewing any concomitant medications.

At the screening visit, AK lesions were assessed clinically and by confocal microscopy and a representative lesion confirmed by histology. Because AK lesions are in general small in size, histology and gene expression analysis could not be performed on the same biopsy. Therefore, confocal microscopy was performed to establish a correlation of the confocal images and their respective non-sun exposed non-lesional skin, sun exposed non-lesional skin, actinic keratoses lesions, and squamous cell carcinoma. All subjects with lesions histologically identified as having a degree of dysplesia suggestive of squamous cell carcinoma were disqualified from the study. All sites identified as AK lesions were marked and a plastic template of their locations made for exact identification at a later time. Thereafter, changes in $\mathrm{AK}$ lesions due to treatment with 
imiquimod were assessed clinically and by confocal microscopy. Lesions were scored as cleared if the skin exhibited normal epidermis as assessed clinically and by confocal microscopy. Assessment of lesion regression and the results of the confocal microscopy as they relate to aberrant gene expression in $\mathrm{AK}$ are discussed in a manuscript submitted for publication (Torres et al, 2006. Micro Array Analysis of Aberrant Gene Expression in Actinic Keratosis: Effect of Imiquimod 5\% Cream).

At the treatment initiation visit, a shave biopsy was taken for gene expression analysis from an untreated AK lesion, from a sun-exposed non-lesional site on the head and from a non-lesional sun-unexposed site from under the arm area. An additional biopsy was taken at each subsequent study visit, (treatment period weeks 1,2, and 4) and at 4 weeks post treatment of either a remaining $\mathrm{AK}$, or if no AKs were present, of nonlesional skin at a previously identified lesional site. Thus each biopsy was of a different AK lesion. In an effort to standardize the amount of tissue that was removed at each biopsy, the same size punch was used to score the skin surrounding all the lesions to be biopsied for gene expression studies with an attempt to shave-biopsy the lesion at the papillary dermis level. Biopsies were taken $8 \mathrm{hr}$ to $16 \mathrm{hr}$ after the third treatment of the treatment period. The nonlesional, sun-unexposed site biopsy was used to establish a baseline for comparison of gene expression changes in AK before and after treatment with imiquimod. Shave biopsies were immediately immersed in RNALater (Ambion, Austin, Texas), equilibrated at room temperature for 1 hour, kept at $4{ }^{\circ} \mathrm{C}$ for 24 hours, and then stored at $-20^{\circ} \mathrm{C}$ prior to RNA extraction.

\section{RNA extraction and purification}

Total RNA from the biopsy samples was extracted and purified using Qiagen RNeasy Mini Kit Protocol for the Isolation of Total RNA from Heart, Muscle and Skin Tissue (Qiagen, Valencia, California) according to manufacturer's instructions. RNA yield varied from 1.5 to $14 \mathrm{ug}$. The purity of the RNA was determined by the $260 \mathrm{~nm} / 280$ $\mathrm{nm}$ absorbance ratio. The median $260 \mathrm{~nm} / 280 \mathrm{~nm}$ ratio value for the 119 samples was 2.0 (range 1.9 to 2.2). RNA integrity was determined using the Agilent 2100 Bioanalyzer and the RNA 6000 Nano Assay (Agilant Technologies, Palo Alto, CA). All samples gave 28S/18S ratio between 2 and 3 indicating good quality RNA.

\section{Micro array analysis}

Samples for micro array analysis were prepared by 2 rounds of linear target amplification according to the Affymetrix instructions for eukaryotic small sample preparation $[28,29]$. Briefly, double-stranded cDNA was synthesized from $100 \mathrm{ng}$ of total RNA with oligo(dT)24T7 primer (Affymetrix, Santa Clara, California), followed by
2 cycles of in vitro transcription of cRNA. The first cycle of invitro transcription was performed using a T7 polymerase (MEGAscript T7 Kit, Ambion, Austin, Texas) and the second cycle using Enzo BioArray High Yield RNA Transcript Labeling Kit (Affymetrix). The median value for the biotinylated cRNA yield over the 119 samples was 90 (range 42 to 121). The biotinylated cRNA was hybridized to Affymetrix U133A and U133B GeneChip arrays containing 22,253 probes sets each. Each array was hybridized for 16 hours, washed, then stained with streptavidin-phycoerythrin conjugate and scanned according to manufacturer's instructions. Images were analyzed using Micro Array Suite Version 5 (MAS5). Chips were normalized to a global average intensity of 150 to allow chip-to-chip comparison. The quality of the images was ascertained by monitoring the noise, background, percent transcript present, and the 3'/5' ratio for the housekeeping gene glyceraldehyde-3-phosphate dehydrogenase (GAPDH) which ranged from 1.5 to 5 and beta actin which ranged from 7 to 24 . These values are similar to those reported for double amplification protocols [29,30].

\section{TaqMan $^{\mathrm{TM}}$ real time reverse transcriptase polymerase chain reaction}

TaqMan real time RT-PCR was performed for a number of the genes to confirm the micro array results. CDNA was reverse transcribed from total RNA using Invitrogen Superscript First-Strand Synthesis System for RT-PCR (Invitrogen, Carlsbad, California). Real time RT-PCR was performed using the Applied Biosystems $7900 \mathrm{HT}^{\mathrm{TM}}$ sequence detection instrument (Applied Biosystems, Foster City, California), and TaqMan low density custom array micro fluidic cards (Applied Biosystems, Foster City, California) as described previously[31]. The micro fluidic cards consisted of 8 ports with 24 different TaqMan primer pair/ probe sets arrayed in duplicate in a 384-well micro plate footprint. Each well contained a gene-specific forward and reverse primer, as well as a gene-specific probe, which is labeled at the 5' position with 6FAM (areporter dye) and at the 3' position with minor groove binder/non-fluorescent quencher. Samples were mixed with TaqMan Universal PCR Master Mix (Applied Biosystems, Foster City, California), applied to each port of the card, and analyzed by PCR on the 7900HT instrument using Applied Biosystems Sequence Detection System 2.0 software according to the manufacturer's instructions. A total of 46 selected genes associated with the Toll-like receptor pathway, apoptosis, cell cycle, and immune cell infiltration were analyzed using the TaqMan arrays. The housekeeping gene glyceraldehyde-3-phosphate dehydrogenase (GAPDH) was used to normalize each sample. The TLR copy number was calculated for 2 ng of RNA. 


\section{Analysis of affymetrix gene chip data}

Signals from the gene chip images of biopsy samples for untreated normal skin obtained from sun-unexposed sites were used as a control for the calculation of changes in expression in samples of pretreatment AK lesions and AK lesions during and after treatment (treatment weeks 1, 2, and 4 and 4 weeks post treatment). The statistical algorithm in MAS5 evaluates the image for the expression signal, the absent/present call, and the p-value associated with the signal. It also evaluates the fold change of the sample relative to the designated control sample expressed as the signal $\log 2$ ratio, the $\mathrm{p}$-value associated with the fold change, and the direction of change (increased, I; decreased, D; or no call, NC). Using the Affymetrix data mining tool software, the expression data from MAS5 were filtered on the basis of specific criteria to identify differentially expressed genes. A given gene was retained if 1 sample from the series passed the following criteria: signal detection p-value $\leq 0.01$, signal $\log 2$ ratio $\leq$ -2 or $\geq 2$, and a change call designation of 'increased' (I) or 'decreased' (D). A total of 1682 genes passed these criteria.
There was a large subject-to-subject variation in the magnitude of changes in expression, as well as the temporal pattern of expression (subject-specific variation in magnitude of response with treatment time) of the 1682 genes. This variation is exemplified in Figure 1, which shows the variation in the temporal expression of IRF7 for selected subjects. Peak expression varied from week 1-treatment to week 4 -treatment depending on the subject. This variation may be due to the inherent differences in the responses of subjects and (or) due to variation in the time from treatment to biopsy (range 8 to $16 \mathrm{hr}$ ). In order to identify differentially expressed genes in the treatment group without regard to variation in temporal response, the data were reduced in the following manner. The fold change values for samples in the week 1, week 2 and week 4 treatment groups for the 1682 genes for each subject were compared to identify the maximum change in expression (increased or decreased) due to imiquimod or placebo treatment. This value was designated as the treatment-response fold change for imiquimod or placebo and used in the ANOVA described in the Statistical Analysis section.

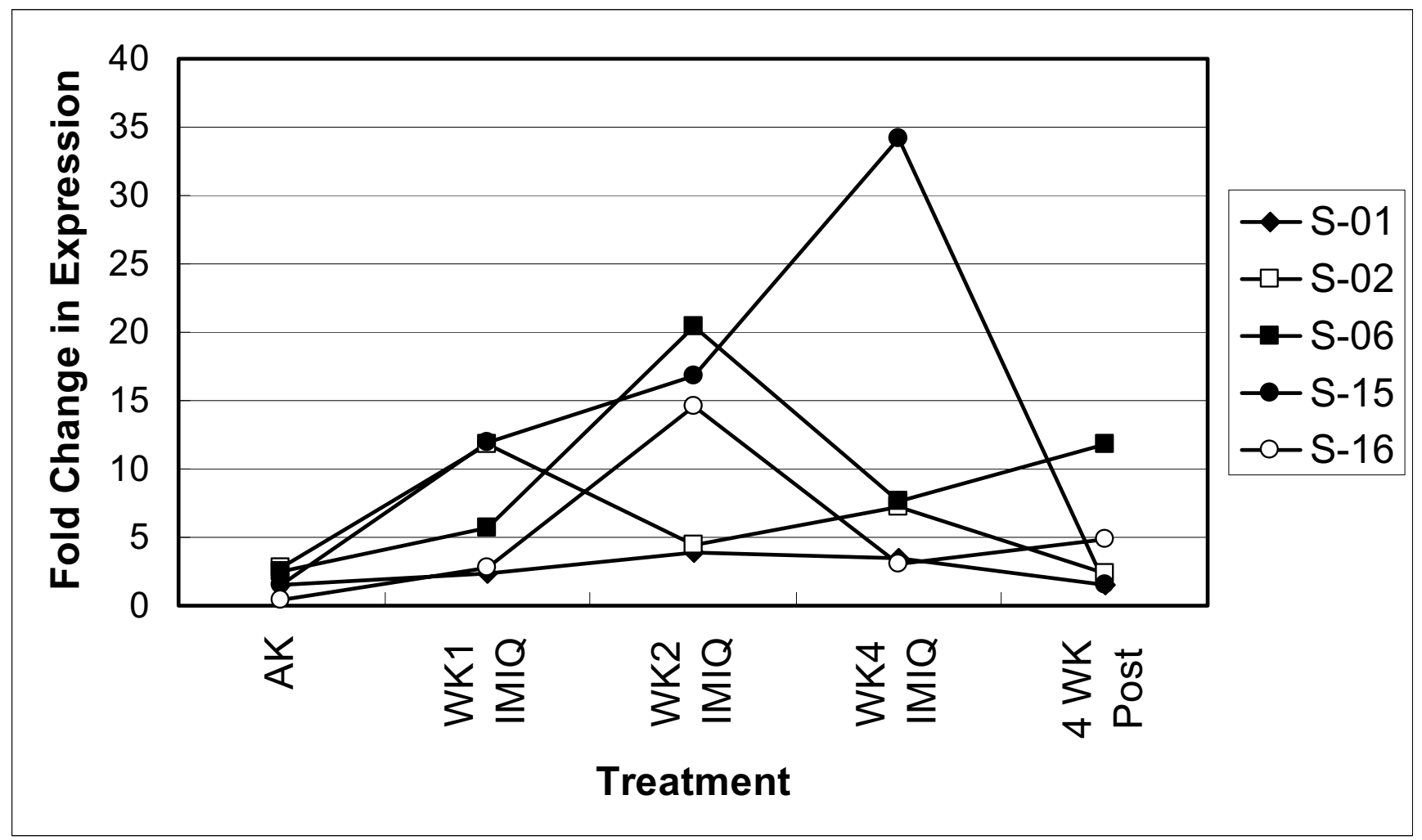

\section{Figure I}

Variation in the temporal expression of IRF7 during treatment with imiquimod as determined by real time RT-PCR. 'AK,' designates pretreatment AK lesions. 'WKI IMIQ', 'WK2 IMIQ' and 'WK4 IMIQ' designate treatment times week I, 2 and 4 . '4 WK Post designates' 4 weeks post end of treatment (WK4 treatment). Fold change was calculated with respect to sun-unexposed, non-lesional skin. S-0I, S-02, S-06, S-I5 and S-16 are samples from subjects I, 2, 6, I5 and 16. 
Cluster analysis was performed with Spotfire DecisionSite-8.1 for Functional Genomics (Spotfire Inc, Somerville, Massachusetts), using the Unweighted Pair-Group Method with Arithmetic mean (UPGMA) and the Euclidean similarity measure. Functional categorization of genes was based on gene ontology analysis using the Ontology Browser in Spotfire and gene descriptions at the National Center for Biotechnology Information (NCBI) website [32]. The ontology browser calculates a Fisher's Exact Test p-value, which reflects the chance that the gene ontology category is represented by random chance [33]. $P$-value $<0.05$ is considered significant.

\section{Statistical analysis}

The natural log of the fold change (with respect to sununexposed normal skin) from the Affymetrix gene expression and the real time RT-PCR experiments were used in an ANOVA to determine statistically significant changes in expression between sample groups. Due to the small sample size of the vehicle group, 4 subjects, compared to 13 subjects in the imiquimod-treated group, a one way ANOVA comparing vehicle-treated subjects to imiquimod-treated subjects is not expected to yield a reliable determination of imiquimod-response genes. Therefore, a 2-way ANOVA using a blocking factor to account for repeat observations on the same subject was used to compare: (1) the fold change for pretreatment $A K(n=13)$ and the fold change during treatment with imiquimod $(\mathrm{n}=$ $13)$, and (2) the fold change for pretreatment AK $(n=13)$ and the fold change for samples taken 4 weeks after the last imiquimod treatment $(\mathrm{n}=13)$. The 'during treatment' fold change is the maximum response fold change value (decreased or increased) selected from week 1, week 2 and week 4 treatment fold changes. Differences between sample groups were considered significant if the p-value for the ANOVA was $<0.05$.

\section{Results and Discussion}

\section{Demographics and response to treatment}

Seventeen white males were randomized to receive treatment ( 13 to imiquimod and 4 to placebo). The mean age was 75 years (range, 62 to 89 years). All 17 subjects in the study completed the treatment and post treatment portions of the study. The median number of AK lesions at baseline was 10 per subject (range, 6 to 13 lesions). Because of the short duration of the follow-up period (4 weeks for the post treatment period), efficacy was not measured in this study. However, clinical clearance was observed in $25 \%$ of the imiquimod-treated subjects 4 weeks after the end of treatment. Imiquimod-treated subjects 1, 2, 4, and 6 and placebo-treated subject 7 were assessed as having clinical clearance of lesions 4 weeks post treatment as determined by return of the lesional site to normal skin. The complete clearance rate in a study where AK subjects were treated for 16 weeks, with a post treatment period of 8 weeks, was 57\% [17].

\section{Analysis of global gene expression using Affymetix GeneChips: Gene Ontology classification}

A 2-way analysis of variance (ANOVA) was performed comparing the treatment response gene expression fold change (the maximum response value from week 1 , week 2 and week 4 treatments) of samples from the imiquimod-treated subjects to the gene expression fold change values of their respective pretreatment AK samples. This comparison resulted in 530 unique genes that had p-values $<0.05$ and a median fold change from pretreatment $\mathrm{AK}<-2$ for suppressed genes and $>2$ for induced genes. Data for the 530 genes is documented in [Additional file 1]. Two-way ANOVA comparing pretreatment AK samples and samples taken 4 weeks after the last imiquimod treatment resulted in 111 unique genes that differentiated the 2 groups with a p-value $<0.05$ [see Additional file 1]. The expression of the rest of the genes returned to basal levels 4 weeks post treatment. Of the total number of differentially regulated genes during imiquimod treatment or 4 weeks post treatment, $87 \%$ were up-regulated and 13\% were down-regulated.

Table 1 summarizes the gene ontology classification of imiquimod-modulated genes from the Affymetrix analysis. P-values for representation of ontology categories are given for categories with $\mathrm{p}$-values $<0.05$. Of the 530 unique genes whose expression was modulated by treatment, 436 genes had some annotation in the ontology database. Of these, 106 were annotated to the immune response category, 123 to signal transduction, 72 to receptor activity, and 25 to inflammatory response. Specific genes in several molecular function categories are also listed. Other ontology categories that were represented in the data but had p-values $>0.05$ for representation in the gene ontology category included metabolism (148 genes), development (37 genes) and regulation of transcription (24 genes). The ontology analysis shows that imiquimod treatment of AK results in global gene expression changes impacting various cellular processes, with immune response and signal transduction being the 2 major processes represented.

\section{Validation of selected genes observed in the Affymetrix experiment using real time reverse transcriptase polymerase chain reaction}

Micro array analysis may not be sensitive enough to capture all changes in gene expression. In comparison, real time reverse transcriptase polymerase chain reaction (RTPCR) has been shown to be more sensitive for the detection of low abundance transcripts [31]. Therefore, we analyzed AK samples and imiquimod treated AK samples for a selected set of genes using real time RT-PCR. The data is 
Table I: Gene Ontology Classification of Imiquimod-Induced Genes in AK Lesions

\begin{tabular}{|c|c|c|c|c|c|c|}
\hline Ontology & $\begin{array}{l}\text { Genes in } \\
\text { the Data }\end{array}$ & $\begin{array}{l}\text { Annotated } \\
\text { Genes }^{2}\end{array}$ & P-value ${ }^{3}$ & $\begin{array}{l}\text { Increased } \\
\text { Expression }\end{array}$ & $\begin{array}{l}\text { Decreased } \\
\text { Expression }\end{array}$ & $\begin{array}{l}\text { Description of Processes and Specific } \\
\text { Genes }\end{array}$ \\
\hline Total & 436 & 17479 & & 369 & 67 & \\
\hline Response to stimuli & 137 & 2475 & $2.13 \mathrm{E}-19$ & 125 & 12 & $\begin{array}{l}\text { defense response, response to external biotic } \\
\text { stimuli including, pest and pathogens, } \\
\text { antimicrobial, anti-fungal, anti-viral response }\end{array}$ \\
\hline Defense response & 105 & 1174 & I.54E-40 & 102 & 3 & immune response, inflammatory response \\
\hline Immune response & 106 & 1020 & $3.05 \mathrm{E}-40$ & 104 & 2 & $\begin{array}{l}\text { cellular defense response, humoral defense } \\
\text { response, antigen binding, pattern binding, } \\
\text { cytokine synthesis, chemokine synthesis, } \\
\text { antigen presentation processing, inflammatory } \\
\text { response }\end{array}$ \\
\hline Response to stress & 68 & 1337 & I.77E-12 & 63 & 5 & $\begin{array}{l}\text { response to pest and pathogen, inflammatory } \\
\text { response, response to virus, response to } \\
\text { wounding }\end{array}$ \\
\hline Inflammatory response & 25 & 244 & $4.35 \mathrm{E}-\mathrm{II}$ & 25 & 0 & $\begin{array}{l}\text { defensive reaction (by vertebrate tissue) to } \\
\text { infection or injury }\end{array}$ \\
\hline Response to wounding & 39 & 395 & $3.72 \mathrm{E}-16$ & 39 & 0 & $\begin{array}{l}\text { defensive reaction (by vertebrate tissue) to } \\
\text { physical injury }\end{array}$ \\
\hline Signal transduction & 123 & 3547 & $4.70 \mathrm{E}-06$ & 95 & 17 & $\begin{array}{l}\text { cytokine signaling, death receptor signaling, G- } \\
\text { protein coupled receptor signaling, intigrin } \\
\text { binding, MHC protein binding }\end{array}$ \\
\hline Receptor activity & 72 & 1914 & I.80E-07 & 62 & 10 & $\begin{array}{l}\text { chemokine receptors, pattern recognition } \\
\text { receptors, immunoglobulin receptors, } \\
\text { complement receptors, MHC IMMHCII } \\
\text { receptors, scavenger receptors, } \\
\text { Hematopoietin/interferon class (D200) } \\
\text { receptors }\end{array}$ \\
\hline Antigen binding & 8 & 91 & $2.66 \mathrm{E}-03$ & 8 & 0 & $\begin{array}{l}\text { SCFI, IGLV2-I 4, LAG3, LILRAI, SLAMFI, TRA@, } \\
\text { TRGC2, TAP2 }\end{array}$ \\
\hline Carbohydrate binding & 16 & 326 & I.18E-03 & 14 & 2 & $\begin{array}{l}\text { CCL8, CD69, CLEC4A, FCNI, FGFR2, GALNT7, } \\
\text { HMMR, KLRCI/KLRC2, KLRFI, LGALS2, LGALS9, } \\
\text { POSTN, PTN, SELL, SELPLG, SN }\end{array}$ \\
\hline Pattern binding & 10 & 159 & $4.58 \mathrm{E}-02$ & 8 & 2 & $\begin{array}{l}\text { CCL8, CD I4, FGFR2, HMMR, POSTN, PTN, } \\
\text { TLR2, TLR7, TLR8, TLR4 }\end{array}$ \\
\hline Cytokine receptors & 9 & 99 & I.97E-04 & 9 & 0 & $\begin{array}{l}\text { CCR5, CCRI, CD74, CSF2RB, CXCR4, ILIORA, } \\
\text { ILIRLI, IL2IR, TNFRSFIB }\end{array}$ \\
\hline Cytokines & 12 & 257 & I.IIE-04 & II & 1 & $\begin{array}{l}\text { CCL3, CCL5, CCL8, CXCL5, CXCLI0, CXCLII, } \\
\text { CXCLI 2, CXCLI6, TNFSFI0, ECGFI, PTN, } \\
\text { SLURPI }\end{array}$ \\
\hline $\begin{array}{l}\text { Immunoglobulin } \\
\text { binding }\end{array}$ & 4 & 25 & I.56E-03 & 4 & 0 & FCERIA, FCERIG, FCGR3B, 2 I45II_x_at \\
\hline $\begin{array}{l}\text { Cystein type } \\
\text { endopeptidase }\end{array}$ & 9 & 169 & $8.21 \mathrm{E}-03$ & 9 & 0 & $\begin{array}{l}\text { CASPI, CASP8, CTSB, CTSL, CTSC, STSS, LGMN, } \\
\text { TNFAIP3, USPI8 }\end{array}$ \\
\hline
\end{tabular}

'Number of genes in the data for which annotation was found in the Gene Ontology database.

${ }^{2}$ Total number of gene with annotation in the Gene Ontology database.

${ }^{3 P}$-value for representation of gene ontology category in the data. 
summarized in [Additional File 2] which compares the median fold change values (13 imiquimod-treated subjects) measured using both Affymetrix GeneChip analysis and RT-PCR for a subset of the genes. In general, good agreement was obtained between the 2 methods, with the RT-PCR data showing similar or higher expression than the Affymetrix data. Figure 2 shows a comparison of the 2 methods for the expression of interferon regulatory factor 7 (IRF7). The individual fold change values for the $13 \mathrm{imi}-$ quimod-treated subjects during imiquimod treatment were used for the regression analysis ( $\mathrm{R}$ Square $=0.83$ ). In general, the direction of change in expression for each gene was the same in both assays whereas the magnitude of the fold change values was higher for the RT-PCR analysis than the Affymetrix analysis. Of the 46 genes evaluated on both gene expression platforms, only 3 genes (CD80, MyD88 and TLR6) were identified as having changed in expression in the RT-PCR experiments only ( $\mathrm{p}$ value ANOVA analysis $<0.05$ ). We did not identify any genes that were differentially expressed by the Affymetrix method that were not also differentially expressed by real time RT-PCR. Thus, overall good agreement was obtained between the 2 methods, with differences between the 2 methods likely due to the increased sensitivity and quantitative nature of the RT-PCR platform.

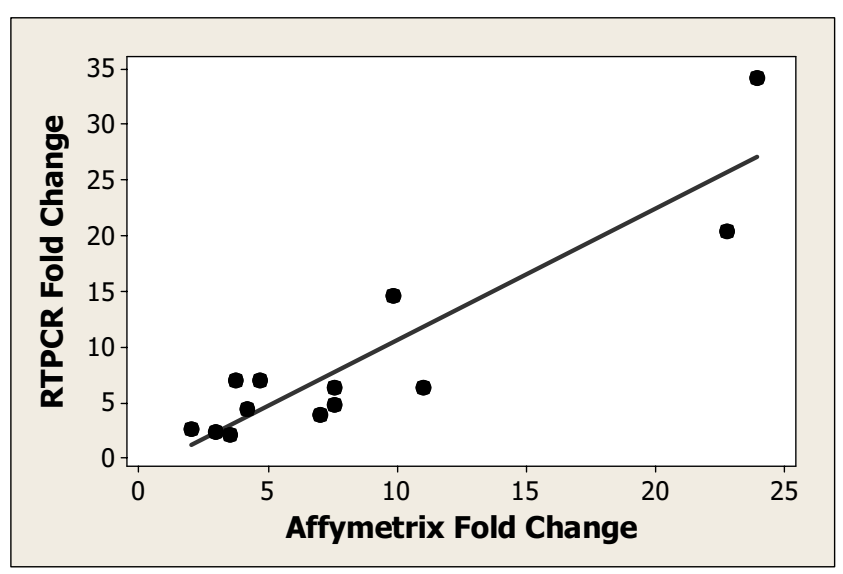

Figure 2

Comparison of gene expression data obtained by Affymetrix GeneChip analysis and real time RT-PCR. Linear regression analysis for IRF7 comparing fold change values for individual subjects as measured by Affymetrix analysis and real time RT-PCR analysis. The imiquimod response fold change, which is the maximum response from week I, week 2 and week 4 treatment times was used. Fold change was calculated relative to sun-unexposed, nonlesional skin samples for 13 subjects treated with imiquimod. The $R$ square value for the comparison was 0.83 .

\section{Imiquimod increases expression of pattern-recognition receptors of the innate immune system}

Since imiquimod is a TLR7 agonist, we sought to determine if TLR7 and other TLRs were expressed in AK lesions and if treatment with imiquimod altered their expression. We analyzed expression levels of various TLRs in biopsy samples of pretreatment $\mathrm{AK}$ and after treatment with imiquimod using RT-PCR. We also measured the expression levels of $M y D 88$, an adaptor molecule for various TLRs including TLR7; and IRF7, a transcription factor recently shown to be important in the regulation of interferon gene expression through the TLR7 pathway [34]. Figure 3 shows the median expression levels of the various TLRs, $M y D 88$ and IRF7 for subjects treated with imiquimod (n $=13$ ) during treatment and 4 weeks post treatment. The expression of TLR1, TLR3, TLR6, TLR7, TLR8, TLR9, $M y D 88$ and IRF7 were all increased at statistically significant levels ( $\mathrm{p}$-value $<0.05$, during treatment [see also Additional File 2]. The increase in TLR4 expression did not reach a statistically significant level $(\mathrm{p}$-value $=0.066$ ) in the imiquimod-treated samples, whereas the Affymetrix data shows a statistically significant increase ( $\mathrm{p}$-value of 0.028 ). The most statistically significant changes observed upon treatment with imiquimod were for TLR3, $T L R 7$, TLR8, and IRF7, with good agreement between the Affymetrix and RT-PCR analysis both for the magnitude of change and for the p-values. There was no change in the expression levels of TLR5 and TLR10 upon treatment with imiquimod. The data are consistent with previous reports of induction of TLRs by various TLR agonists and IFNa $[35-37][38,39]$. The increased expression of the TLRs may be a result of increased expression of the genes in cells resident in the skin (e.g., DCs, macrophages) or due to the influx of cells with high expression of these genes (e.g., DCs, macrophages, plasmacytoid DCs). The increased expression of TLR3,TLR7, and TLR8 is consistent with increased expression observed in human peripheral blood mononuclear cells upon treatment with imiquimod. The data are also consistent with increased expression of TLR7 observed in imiquimod-treated AK [22]. In summary, treatment of AK lesions with imiquimod results in increased expression of several TLRs and TLR pathway components, thus potentially priming for further amplification of the innate immune system. The increase in the expression of IRF7 is also predicted to amplify the innate immune response by increased expression of type 1 interferons and interferon-inducible genes.

In addition to the various TLR(s) which recognize viral and bacterial components, an intracellular antiviral pathway which detects viral RNA and results in the induction of type1 interferons has recently been described [40-42]. The central components of this pathway, which are also inducible by type 1 interferons $[43,44]$ are DDX58 (RIG-I, retinoid acid inducible gene) and IFIH1 (MDA5, 


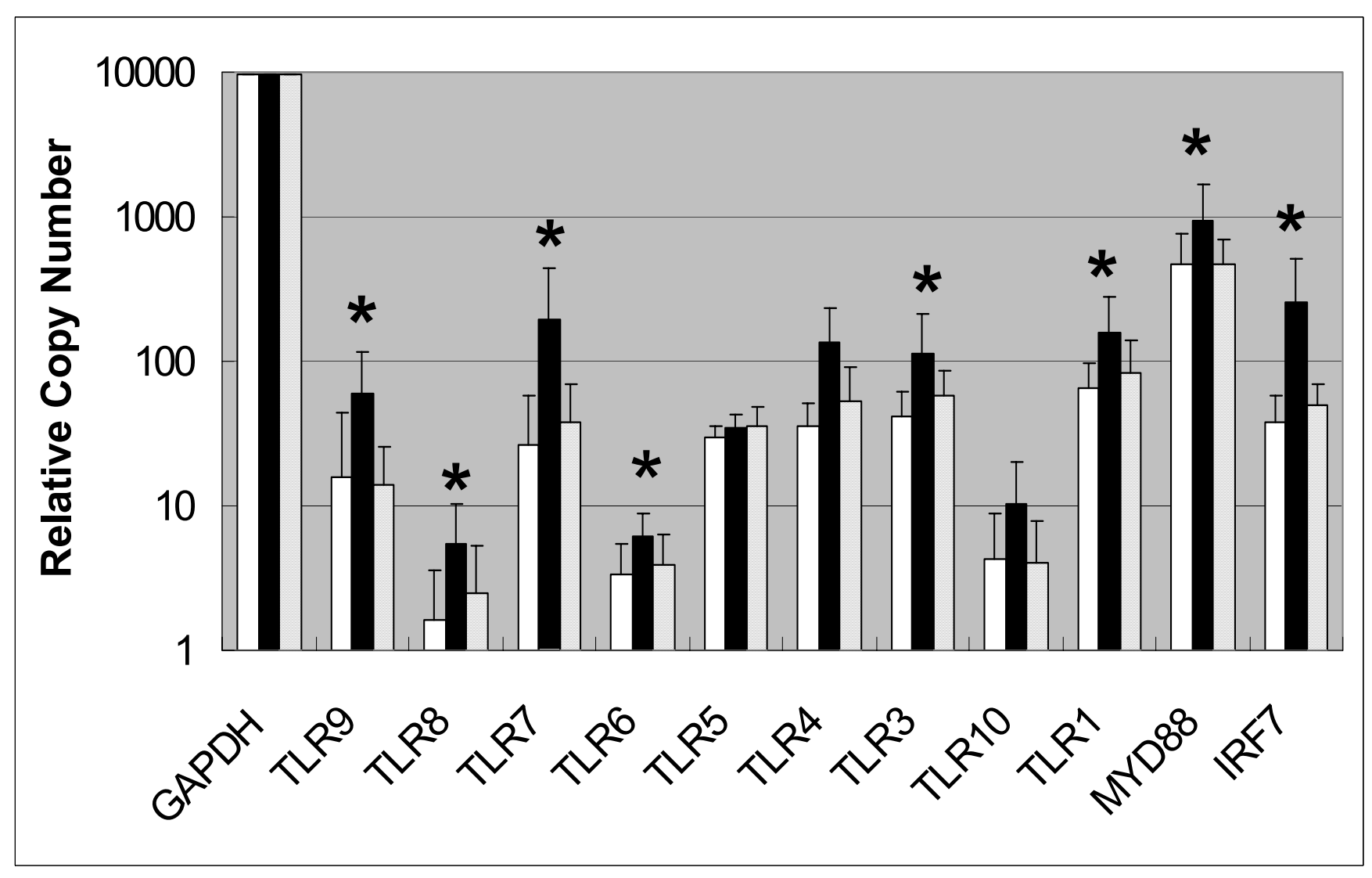

Figure 3

Basal TLR, IRF7, and MyD88 gene expression in skin biopsies as determined by real time RT-PCR. White bars represent pretreatment AK, black bars represent during imiquimod treatment (maximum response value from week I, week 2 and week 4 treatment times), and hatched bars represent 4-weeks post treatment. Relative copy number was determined as outlined in Methods and Materials section. Asterisks indicate those genes that had $p$-values $<0.05$ in the ANOVA, comparing expression in pretreatment $A K$ samples to the maximum response expression in samples from subjects $(n=13)$ during imiquimod treatment. [See Additional file 2].

melanoma differentiation antigen 5). Both genes contain helicase domains responsible for detection of doublestranded RNA. They also contain caspase recruitment domains (CARDdomains), which are responsible for signaling through TBK1 (resulting in activation of NFKB and IRF3), as well as induction of type-1 interferons. The activation of this pathway leads to growth inhibition as well as antiviral activity [45]. Figure $4 \mathrm{a}$ and $4 \mathrm{~b}$ show changes in expression of DDX58 and IFIH1 upon treatment with imiquimod as determined from Affymetrix GeneChip analysis. The expression of both genes was increased to statistically significant levels during treatment. The expression of DDX58 remained higher than its pretreatment level ( $\mathrm{p}$-value $=0.004)$, four weeks, post treatment, whereas that of IFIH1 returned to basal level. The induction of several members of the cytoplasmic helicase innate immune pathway, as well as several TLRs, indicates that in addition to activation of the TLR7 pathway, treatment with imiquimod also results in priming of other innate pathways. These pathways may augment other aspects of the innate immune response and may be important for eliminating pre-neoplastic cells.

\section{Imiquimod induces a large number of type I interferon- inducible genes with growth inhibitory and immune- stimulatory activity}

Imidazoquinoline TLR7 agonists such as imiquimod and resiquimod are know to induce various cytokines, including interferon- $\alpha$, IL6, MCP-1 and IL12 as well as the COstimulatory markers CD80 and CD86 [15,46]. Type I interferons are known to be powerful regulators of the innate and adaptive immune system through the induction of various genes with antiviral, anti-tumor and immune regulatory functions [43,44,47-51]. In this study, we did not detect increased expression of interferon upon treatment with imiquimod, but observed the increased expression of a large number of IFN-inducible genes (114 genes), [see Additional file 3]. The lack of detection of 


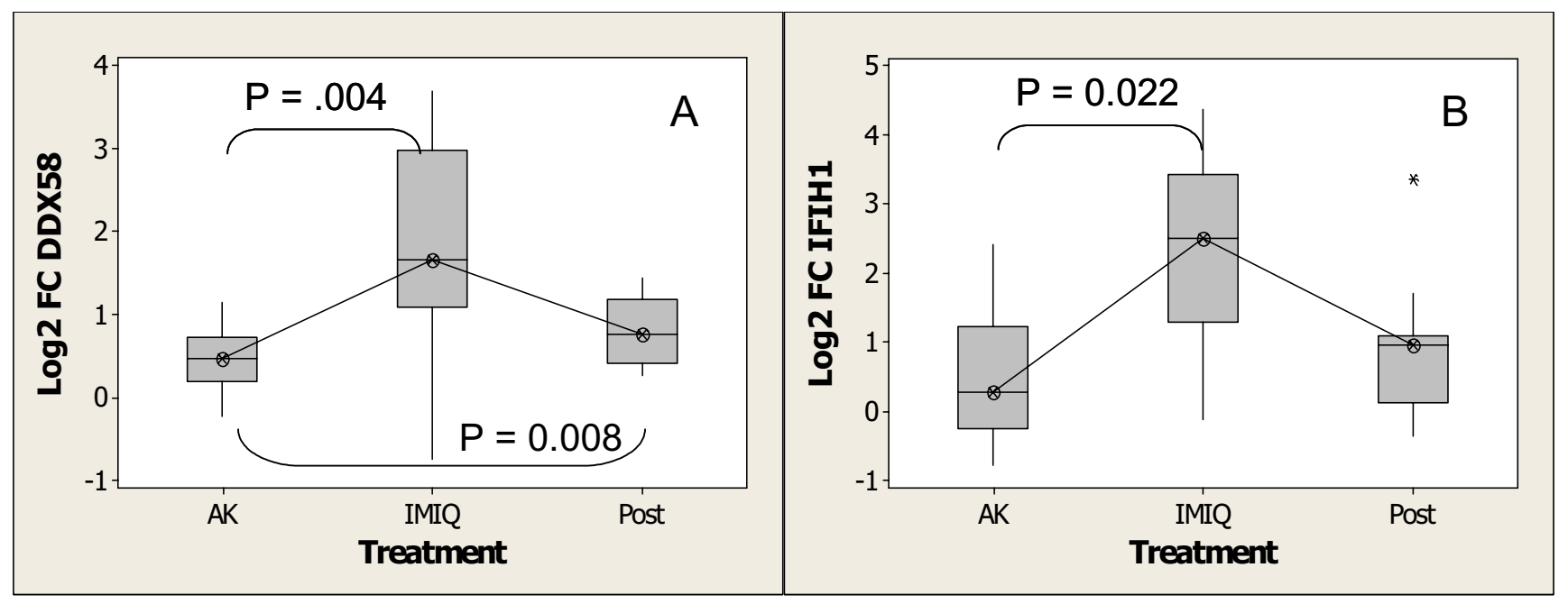

\section{Figure 4}

Increase in expression of the helicase family of virus-sensing genes upon treatment with imiquimod as determined by Affymetrix GeneChip analysis. (A)DDX58 (RIG-I) and (B)IFIHI (MDA5). Experimental conditions are as described in the Methods and Materials section. Box plots were generated using MINITAB version I4. 'AK,' 'IMIQ,' and 'Post' designate pretreatment AK, imiquimod-treated skin during treatment (maximum response from week I, week 2 and week 4), and imiquimod-treated skin 4 weeks post treatment, respectively. Fold change was calculated with respect to sun-unexposed skin. Boxes indicate the median $95 \%$ confidence intervals, asterisks designate outliers, and the lines connect median values. $P$ values are given for 2 -way ANOVA, comparing the fold change values for pretreatment AK samples and imiquimod-treated samples $(n=13)$.

type 1 interferons after imiquimod treatment in this study may be due to the early induction and degradation of their respective mRNA. Biopsies were taken approximately 8 to $16 \mathrm{hr}$ after application of the drug. We have observed that mRNA for type 1 interferons in human blood mononuclear cells treated with imiquimod peaks in 1 to 2 hours and declines to basal levels 6 to 8 hours post treatment (unpublished internal data).

Analysis of gene ontology classification of the interferoninducible genes increased by treatment with imiquimod identified 46 genes with immune response classification. Figure 5 shows a 2-way hierarchical clustering of the $\log 2$ transformed fold changes of all of the 530 imiquimodinduced genes [see Additional file 1]. Figure 6 exhibits clustering of the 46 interferon-inducible genes which classify as immune response genes Two main clusters are apparent in Figure 5. One cluster consists of 8 imiquimodtreated samples. The second and larger cluster consists of all of the pretreatment AK samples, the vehicle-treated samples (designated as placebo in the figure) and five of the imiquimod-treated samples for subjects 02, 05, 09, 12 and 17 (IMIQ-02, IMIQ-05, IMIQ-09, IMIQ-12 and IMIQ-17). The fact that the vehicle-treated samples cluster with pretreatment AK lesions indicates the lack of a significant vehicle-effect in the gene expression profile. In Figure 6,10 of the imiquimod-treated samples appear in 1 cluster, with IMIQ-02 and IMIQ-05 now as part of the IMIQ-treated cluster. This cluster is characterized by high expression of the interferon-inducible genes such as MX1, IFIT1 and IFIT3. The cluster also contains the samples placebo-03 and AK-11, indicating that these AK lesions were already manifesting spontaneous immune response. The imiquimod-treated samples 09, 12, and 17 are clustered with the pretreatment AK samples in both figures, indicating that Subjects 09, 12, and 17 had little gene expression response to imiquimod. Thus, the 46 interferon-inducible immune response genes segregate the imiquimod-treated samples from pretreatment AK and placebo-treated samples better than the whole set of 530 genes. This group of genes may therefore be good predictors of gene expression response to imiquimod. Collectively, these genes have been reported as 'interferon-signature' genes induced by several IFN $\alpha$ subtypes and IFN $\beta$ in monocytes [51].

Heterogeneity of pretreatment AK lesions was not documented by clinical assessment in this study. However, the gene expression profiles shown in Figure 5 and Figure 6 indicate heterogeneity in lesions. In addition to AK 11 and Placebo 03 in Figure 6 which cluster with the imiquimod treatment group indicating some level of immune response in these samples, other AK lesions also show low levels of expression of interferon inducible genes. For example, AK 06, AK 03, and AK 07 show low levels of 


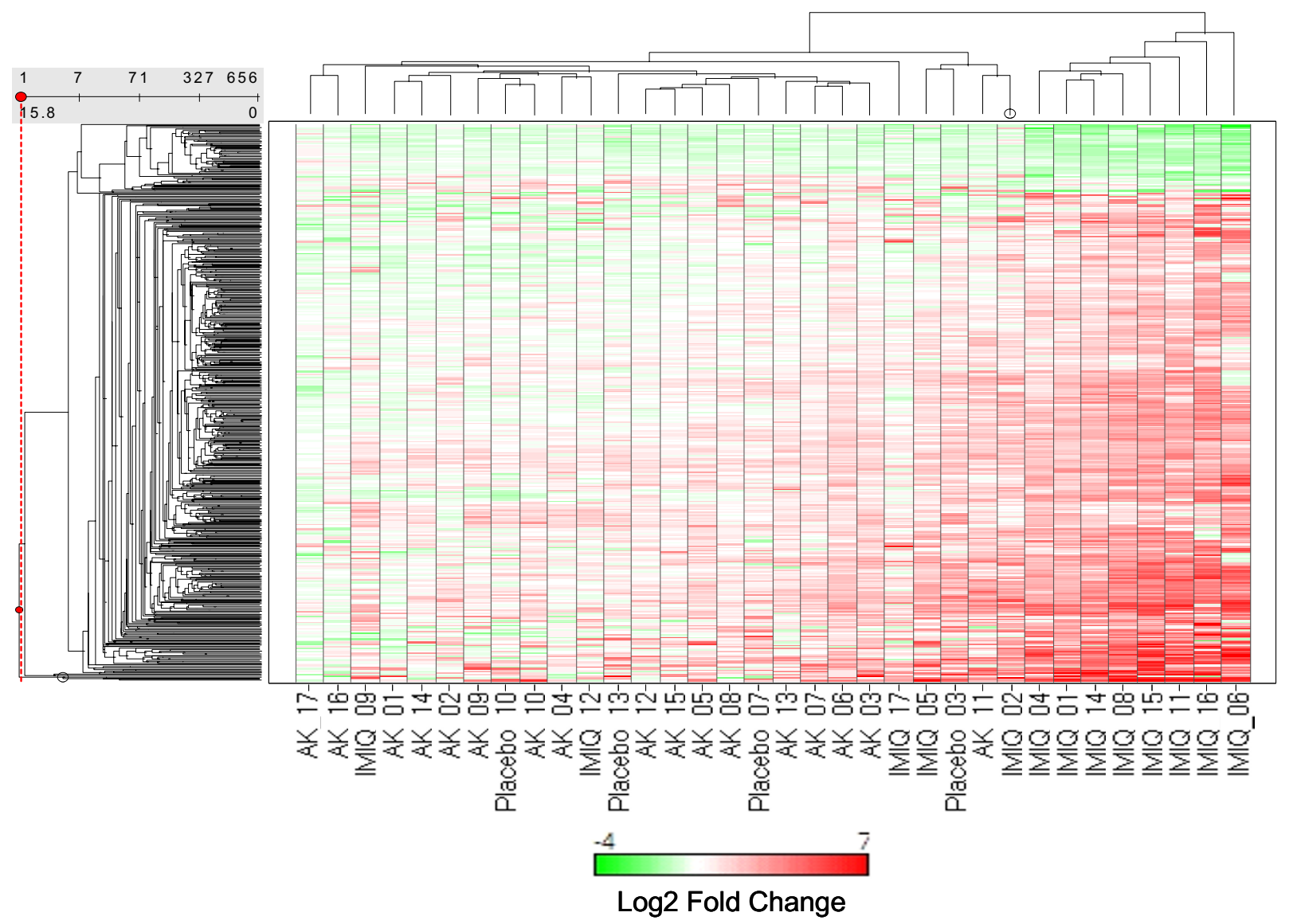

\section{Figure 5}

Cluster analysis of genes regulated by imiquimod treatment. Two-way hierarchical clustering was performed as described in the Methods and Materials section. 'AK,' 'IMIQ,' and 'Placebo' designate the fold change with respect to sun-unexposed, nonlesional skin for pretreatment AK samples; for samples during imiquimod treatment (maximum response from week I, week 2 and week 4), and samples for vehicle-treatment (maximum response from week I, week 2 and week 4) respectively. Numbers designate subjects. Hierarchical clustering was performed using the Unweighted Pair-Group Method with Arithmetic mean (UPGMA) and the Euclidean similarity measure. Red, white, and green indicate up-regulated, unchanged, and down-regulated genes, respectively. The color bar insert shows the corresponding expression levels. The cluster consists of 530 imiquimodresponsive genes whose expression was statistically different when comparing the AK group of samples to the IMIQ group of samples. Expression changes for the 530 genes are documented in [Additional file I].

expression of several interferon-inducible genes whereas AK 16, AK 17, AK 12 and AK 15 show normal to slightly depressed levels (Figure 6).

Interferon-inducible genes regulate diverse cellular processes, such as cell growth and differentiation, cell death, and T-cell co stimulation, activation, and migration. These genes have been reported to possess antiviral [5254], pro-apoptotic [55-57], and anti-proliferative activities [58,59]. The interferon-inducible genes which increased following imiquimod treatment include those known to be induced by viruses as well as those with known anti-viral activity. These include the 2'5'-oligoadenylate synthetases OAS1, OAS2, OAS3 and OASL, the genes encoding the interferon-inducible proteins with tetratricopepetide repeats, IFIT1, IFIT2, and IFIT3, IFTM1, and other interferon inducible genes such as IFI35, IFI16, MX1, MX2, EIF2AK2 (PRKR), G1P2 (ISG15), G1P3, ISG20, RSAD2 (Cig5), CCL8 (MCP2), CXCL10 (IP10) and CXCL11 (ITAC) $[43,44,47,49-52,54,60,61]$. Several of the interferon-inducible genes were also increased at statistically significant levels 4 weeks post treatment. These 


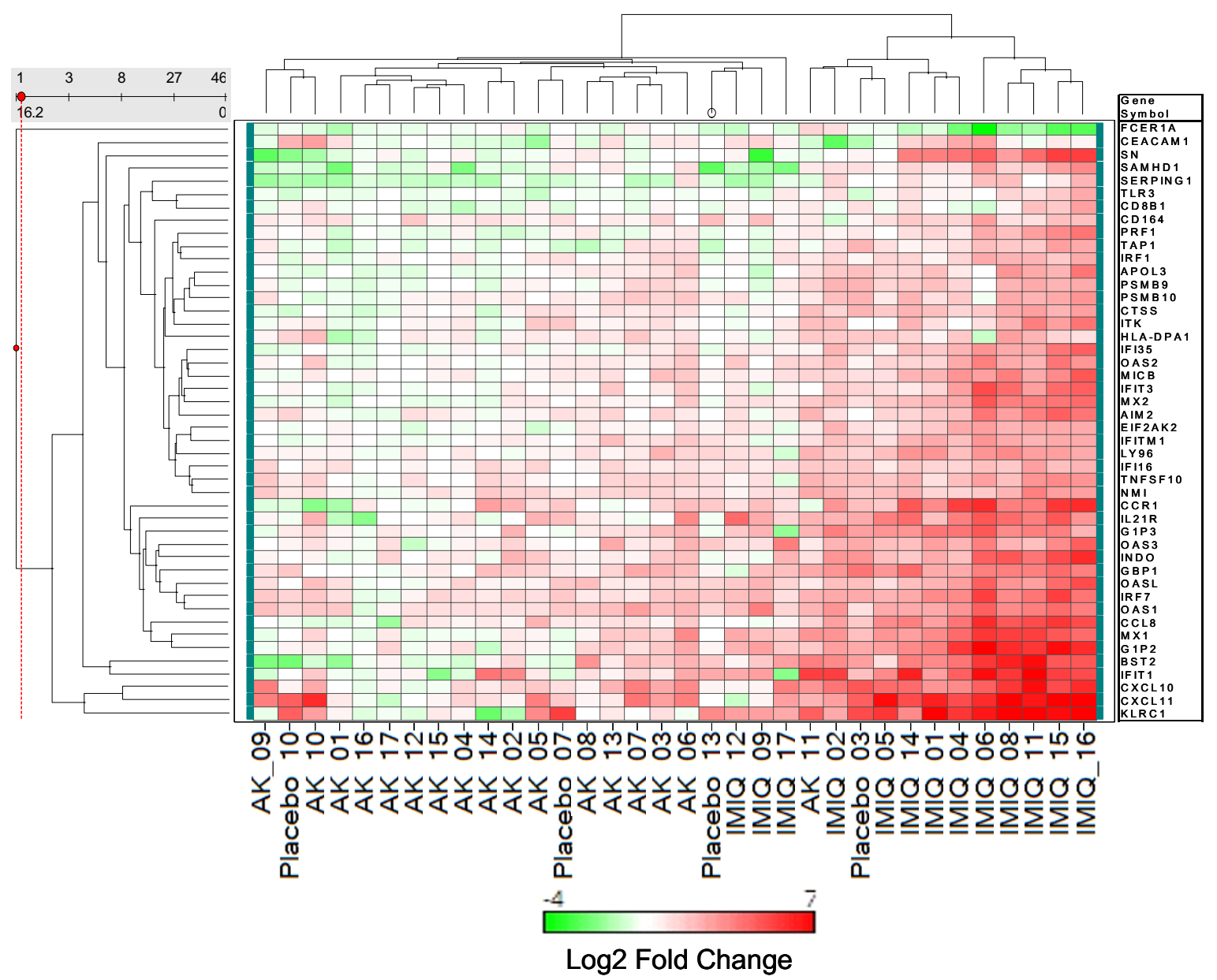

Figure 6

Cluster of 46 immune response genes that are also known to be inducible upon treatment with type I interferons as reported in [18, 43, 45, 48, 5I, 102] Cluster analysis was performed as described in Figure 5. [See Additional file 3].

included: IRF7, IFI44, IFIT2, IFIT3, IFITM1, IFI35, RSAD2 (Cig5), G1P2, MX1, OAS1, and OAS2 [see Additional file $1]$.

In addition to interferon-inducible genes with antiviral activity, several genes known or predicted to possess growth-inhibition and/or cell-differentiating activities $[49,50]$ were induced by imiquimod, including IFI16, AIM2 [62,63], IFIH1 (melanoma differentiation antigen, MDA5) [45], CXCL10 (IP10) [58] and EIF2AK2 (PRKR) [64]. Some of the interferon-inducible genes also possess pro-apoptotic activity, including MX1, TNFSF10 (TRAIL), OAS1, and PRF1 $[55,57,65]$. Figure $7 \mathrm{a}$ and Figure $7 \mathrm{~b}$ show changes in the expression of the pro-apoptotic genes TNFSF10 (TRAIL) and MX1 with imiquimod treatment as determined from the Affymetrix analysis. The expression of $M X 1$ remained elevated at statistically significant level 4 weeks post treatment, whereas the expression of TNFSF10 returned to basal levels. The data are consistent with the observation of increased expression of IFN $\alpha$ inducible genes in imiquimod-treated BCC and cutaneous T-cell lymphoma (CTCL) $[66,67]$. Thus, interferoninducible genes with pro-apoptotic activity (e.g., MX1, TNFSF10) and growth inhibitory activity (e.g., IFIH1, AIM2, IFI16) may result in growth inhibition of neoplastic cells whereas those with immune-stimulatory activity such as CXCL10 (IP10), CXCL11 (ITAC), and CCL8 (MCP2) may facilitate cell-mediated lesion destruction by recruiting immune cells into the lesions. Indeed, further evidence for the recruitment of immune cells into AK lesions with imiquimod treatment is presented in the following sections. 


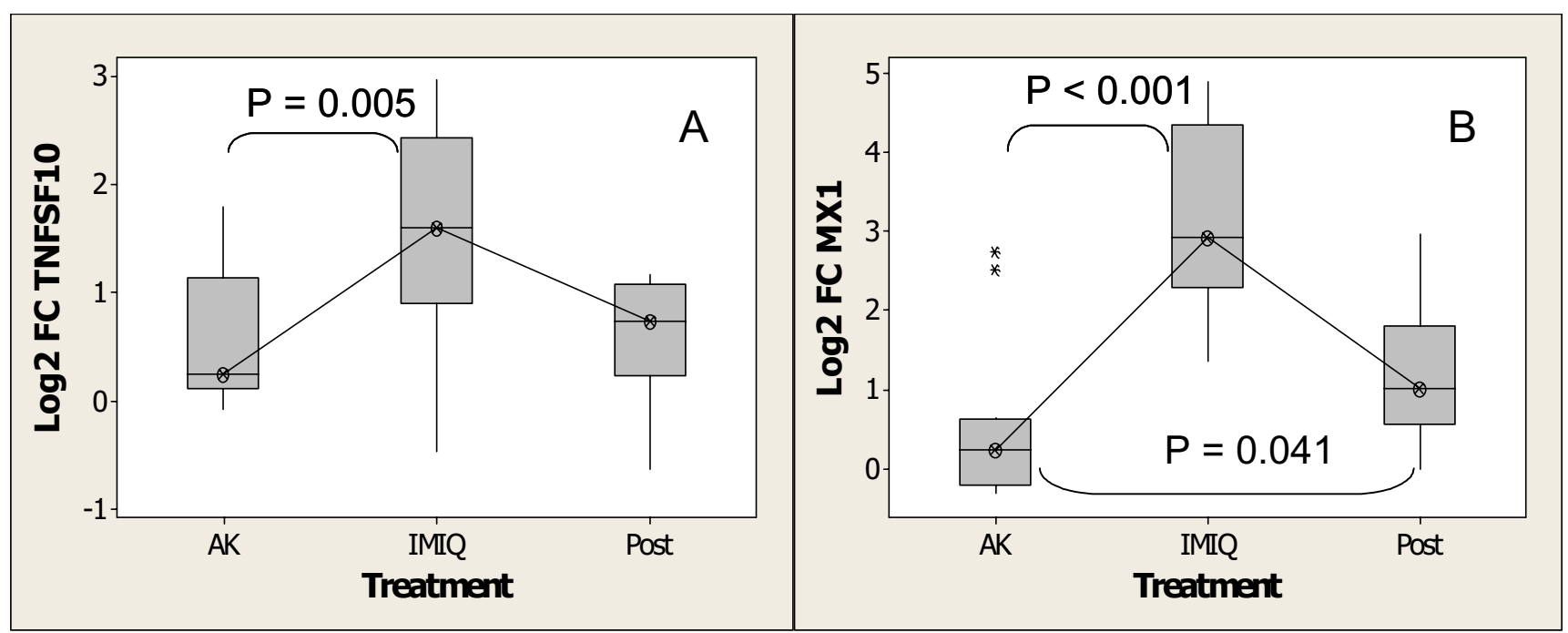

\section{Figure 7}

Imiquimod treatment is associated with an increase in expression of pro-apoptotic genes as determined by Affymetrix GeneChip analysis. (A) TNFSFIO (B)MXI. Experimental conditions and analysis are as described for Figure 4.

Imiquimod induces the expression of chemokines responsible for recruitment of immune cells to $A K$ lesions Gene ontology classification (Table 1) shows that 106 genes classified as immune responsive were induced by imiquimod, some of which are also shown to be interferon $\alpha / \beta$-inducible [see Additional File 3]. Out of the 106 immune response genes, several were classified as cytokines/chemokines and chemokine receptors. In addition to CXCL10, CXCL11 and CCL8 mentioned above, other chemokines were induced by imiquimod treatment, including CCL3 (MIP1a), CCL4 (MIP1b), CCL5 (Rantes), CXCL12 (SDF1), and CXCL16, and the chemokine receptors CCR1, CCR5, and CXCR4. Figure 8a and 8b illustrate changes in expression of CXCL10 and CXCL11 observed upon treatment of AK lesions with imiquimod. The magnitude of the changes observed in the expression of chemokine genes during treatment ranged from a median fold change value of 1.8 for CXCL12 (SDF1) to 40.8 for CXCL11. The expression of both genes returned to pretreatment levels 4 weeks post treatment. These data are consistent with previous reports of increased expression of chemokines genes and their receptors upon topical treatment of BCC and CTCL with imiquimod [67], as well as in vitro studies of human blood mononuclear cells stimulated with other imidazoquinoline TLR7 agonists showing the induction of CXCL10 and CXCL11 proteins [46]. The cocktail of chemokines up-regulated by imiquimod is consistent with recruitment and/or activation of macrophages, DCs, plasmacytoid DCs, gamma/delta T cells, cytotoxic T cells, and natural killer (NK) cells, and is also consistent with the cell surface markers indicating the presence of these cells upon imiquimod treatment. Indeed, topical treatment of various neoplastic skin conditions with imiquimod cream have shown inflammatory conditions at the site of treatment, indicating the infiltration of immune cells into the site $[17,19,20,68,69]$. In this study, the gene expression fingerprints that indicate recruitment of various immune cells are further discussed below.

\section{Imiquimod increases the expression of genes predictive of infiltrating macrophage and dendritic cells}

Of the imiquimod-induced genes classified as immune response in gene ontology, several have receptor activity and (or) are hematopoietic cell surface markers (Table 1). The increased expression of these genes indicates the recruitment of various immune cell types to the lesion sites. Macrophage and/or monocyte infiltration of $\mathrm{AK}$ lesions upon treatment with imiquimod was indicated by an increase in CD14, CD163, and CLECSF9 (CLECSF4, MINCLE), a C-type lectin found on activated macrophages [70]. The increase in expression of genes of the classical complement pathway, C1QA, C1QB, C3AR1, and $C 5 R 1$, also indicates an increase in and/or the activation of macrophages [71]. The data are consistent with histologic observation of macrophage and/or monocyte infiltration after application ofimiquimod in the treatment of AK [72] and in lentigo maligna $[73,74]$.

The presence of DCs is shown by increases in the co stimulatory molecules CD86 and CLEC4A (DCIR, CLECSF6), as well as by 3 leukocyte immunoglobulin receptors: 

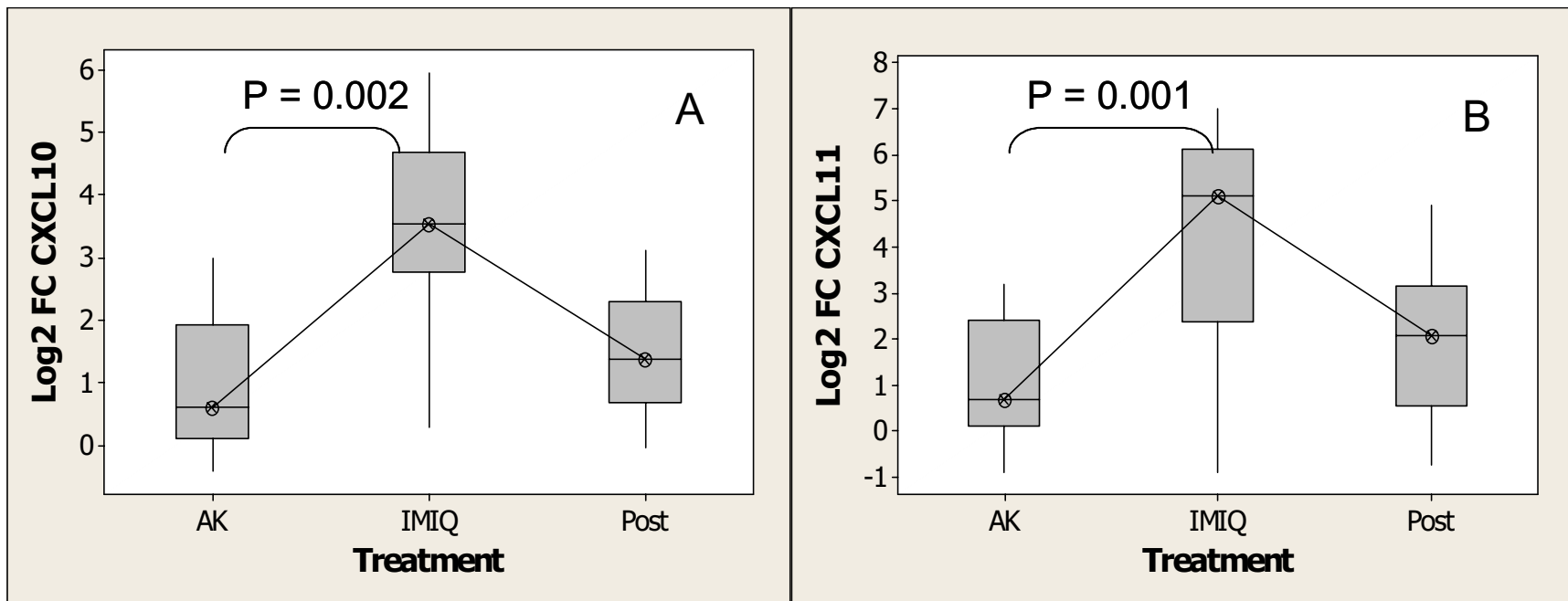

Figure 8

Increase in expression of chemokines after treatment with imiquimod as determined by Affymetrix GeneChip analysis. (A)CXCLIO (IPIO), (B)CXCLI I (ITAC). Experimental conditions and analysis are as described for Figure 4.
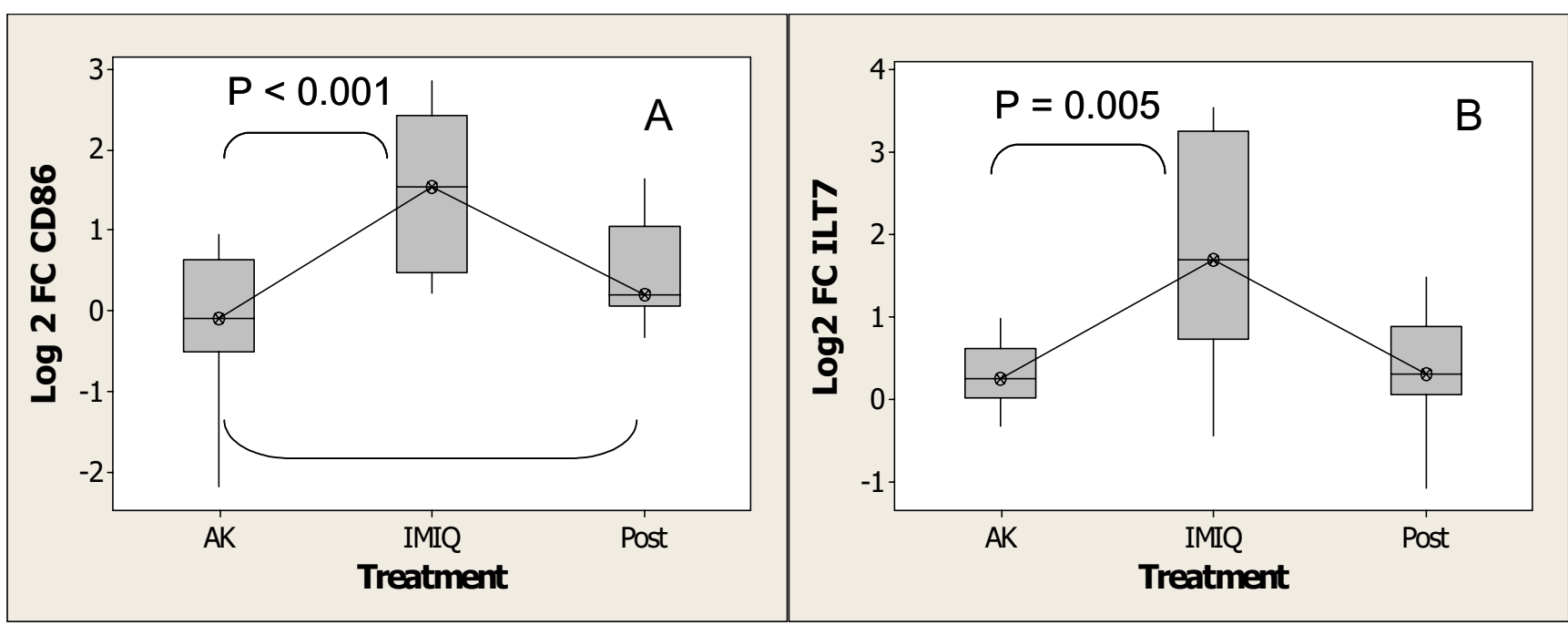

\section{Figure 9}

Increase in expression of genes indicating the infiltration of DCs upon treatment with imiquimod as determined by Affymetrix GeneChip analysis. (A)CD86 (B) ILT7. Experimental conditions and analysis are as described for Figure 4. 
LILRB3 (ILT3) and LILRB1 (ILT2) which are expressed in both myeloid and plasmacytoid DCs [75], while ILT7 (LILRA4, CD85g) is restricted to plasmacytoid DCs $[76,77]$. Figure 9a and Figure 9b illustrate the increase in expression of CD86 and ILT7 with imiquimod treatment. The expression of CD86 remained elevated 4 weeks post treatment. Increased expression is taken as indication of recruitment of these cells to the site of treatment. These observations are consistent with previous studies using topically-applied imiquimod in the treatment of human BCC [69] and melanoma in mice [78], showing recruitment of plasmacytoid DCs into the site of treatment.

It is interesting to note that $C D 1 C$ is markedly decreased upon treatment with imiquimod [see Additional file 3]. CD1c is found on Langerhans cells as well as on DCs $[79,80]$. The decrease in CD1C expression may reflect (although not exclusively) the migration of CD1C+ Langerhans cells out of the dermis. Migration of Langerhans cells out of mouse dermis was observed after topical treatment with imiquimod $[78,81]$. In the case of the Palamara studies [78] in mouse melanoma, Langerhans cells were observed to return to normal levels in the dermis by day 20. The decrease in CD1C observed upon treatment of AK lesions with imiquimod therefore suggests the activation and migration of Langerhans cells to the lymph nodes and is consistent with previous observations.

Imiquimod increases the expression of genes predictive of infiltrating cytotoxic $T$ cells and natural killer cells

Natural killer cells mediate lysis of tumor cells as well as virally-infected cells. Natural killer cells preferentially express several calcium-dependent (C-type) lectins, known as the NKG2 family, which have been implicated in the regulation of NK cell function, and are believed to be important for NK cell-mediated tumor rejection and Tcell mediated immunity [82]. Transcripts for 3 of these Ctype lectins, KLRC1/C2, KLRK1 (NKG2D) and KLRF1 were increased in expression in imiquimod-treated samples. In addition, several genes important to the cytolytic function of NK cells and cytotoxic T cells, including TYROBP (DAP12) and CD69 (early T-cell activation antigen), ITGAL (CD11a), ITGB2 (CD18), ICAM1, and the ligands for the NKG2 receptors, MICA and MICB [Additional file 1] [83-88] were increased in expression with imiquimod treatment. Also, genes of the granule products of NK cells and cytotoxic T cells, such as granzymes GZMA, GZMB, GZMK, and GYNYL (granulysin, NKG5), PRF (perforin) and NKG7 (GIG1, GMP-17) were increased in expression, indicating that these cells are cytolytically active [89-93]. Figure $10 \mathrm{a}$ and $10 \mathrm{~b}$ show changes in the expression of GZMA and NKG7 after imiquimod treatment. The expression of both genes returned to pretreatment levels 4 weeks post treatment. Thus, the coordinate increased expression of genes important for NK cell recognition of tumor cells, and for the activation and cytolytic response of NK cells and cytotoxic T cells, suggests that these cells are at least in part responsible for the antilesional activity of imiquimod.

Imiquimod increases the expression of genes predictive of the activation of the adaptive immune system

The presence of activated T cells in imiquimod-treated AK lesions is indicated by the expression of several members

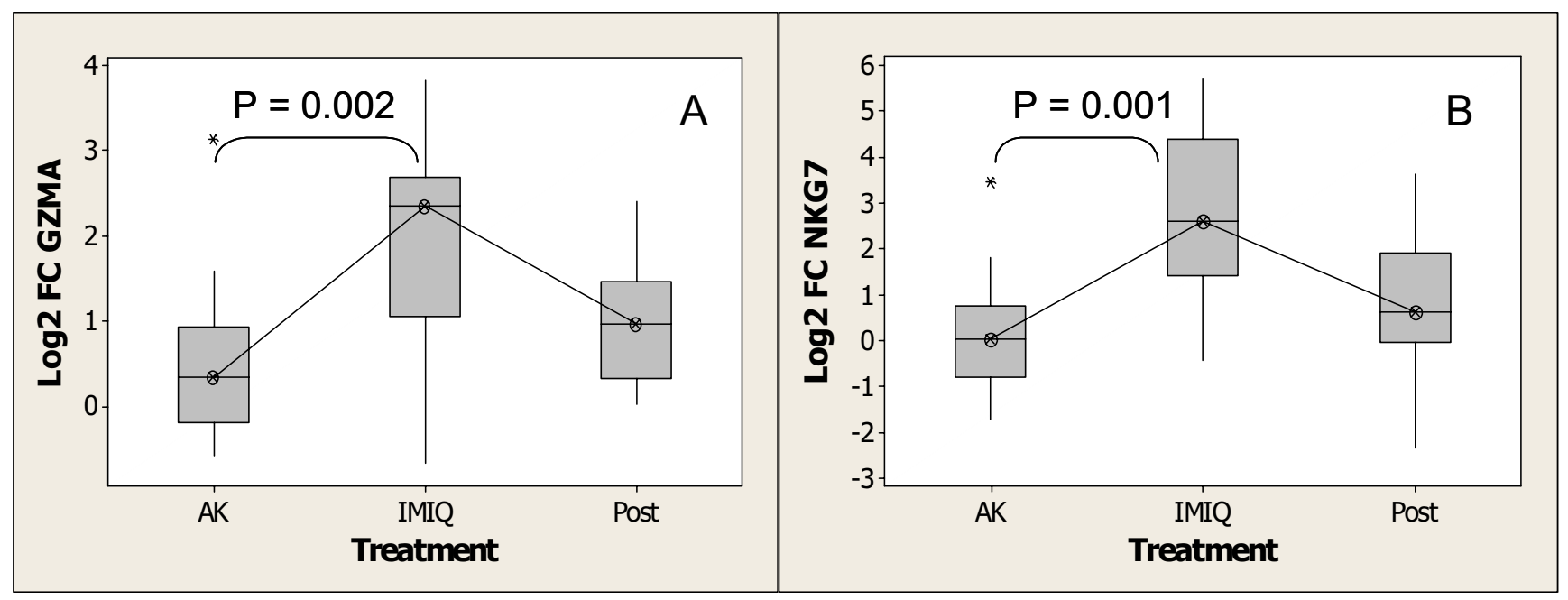

Figure 10

Increase in expression of genes associated with NK cells, and cytotoxic T cells after treatment with imiquimod as determined by Affymetrix gene expression. (A)GZMA (B) NKG7. Experimental conditions and analysis are as described for Figure 4. 

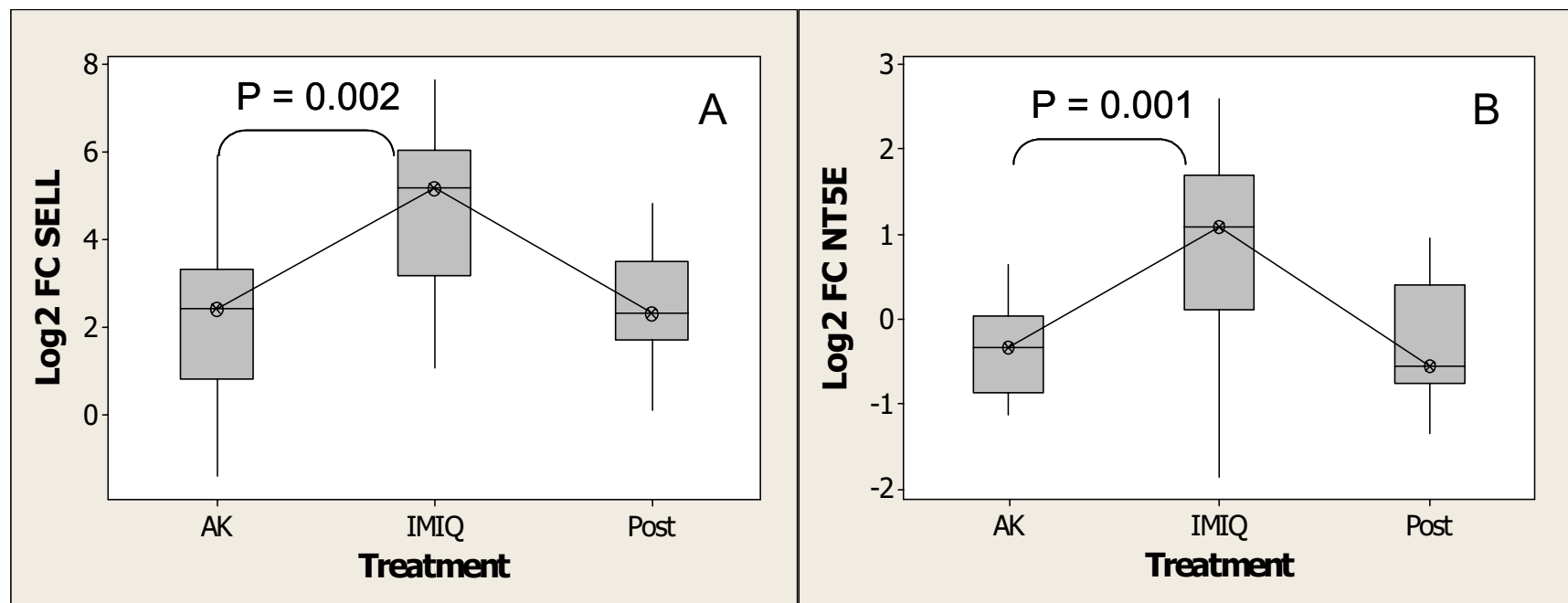

Figure I I

Increase in expression of genes associated with lymphocyte function after treatment with imiquimod as determined by Affymetrix GeneChip analysis. (A) SELL (CD62L) (B) NT5E (DC73). Experimental conditions and analysis are as described for Figure 4.

of the T-cell activation pathway [Additional File 1]). These include the T-cell receptor (TCR) subunits TRD and TRG, TCR-signaling pathway genes such as Fyn, Fyb and LCP2 $[94,95]$, and other genes associated with T-cell activation such as HCK, CD69, PTPRC (CD45) SELL (CD62L, LSelectin), ITGA4 (antigen CD49D, alpha 4 subunit of VLA-4 receptor), and LAG3. In addition, treatment of AK lesions with imiquimod resulted in a small but significant increase in the expression of $\mathrm{CD} 8 \beta$, suggesting that there is an increase in CD8 T cells [96,97]. The presence of CD8 memory T cells in imiquimod-treated subjects is also suggested by increases in expression of SELL, NT5E (CD73), LGALS2 (galectin 2), and LAIR1 (leukocyte-associated immunoglobulin-like receptor 1 ), which was recently identified to be differentially expressed in mouse memory Tcells [98]. Figure 11a and Figure 11b illustrate the increase in expression of SELL and NT5E respectively. The expression levels of these genes returned to pretreatment levels 4 weeks post treatment. Taken together, the increased expression of Tcell receptor genes, T cell activation marker genes and genes important for T cell co stimulation suggests that treatment with imiquimod results in the infiltration of $\mathrm{T}$ cells into AK lesions. The increased expression of genes important for the development of Tcell memory (e.g. SELL, NT5E), as well as genes associated with cytotoxic T cells (e.g. granzymes and perforin) suggests that imiquimod treatment recruits both memory and effector T cells. These results are consistent with the observation of increased CD3, CD4 and CD8 positive cells after topical application of imiquimod to AK lesions [72], as well as infiltration of CD8 T cells in BCC $[19,66]$ and in cutaneous squamous cell carcinoma treated with topical imiquimod [99]. The increased expression of genes important in the activation and co stimulation of cells of the adaptive immune system is consistent with the infiltration of cells important in the development of the adaptive immune system. These observations are also consistent with the reported adjuvant activity of imiquimod and its analog resiquimod [26], and the low recurrence rates observed in animal studies [100] and clinical studies with imiquimod [101]. These same observations suggest that imiquimod may also prevent recurrence of AK lesions as well.

In summary, the data suggest that the therapeutic effect of imiquimod in the treatment of AK involves the stimulation of both the innate and adaptive immune responses. The role of type 1 interferons in imiquimod's mechanism of action is underscored by the induction of large numbers of IFN $\alpha / \beta$-inducible genes with tumor growth-inhibitory and immune stimulatory activity. Data indicate that the antilesional activity of imiquimod is a result of the induction of a strong immune cell-mediated cytolytic and apoptotic gene expression program that leads to destruction of AK lesions and sun-damaged cells. The development of immune memory indicated by this study, as well as the observation of low recurrence in clinical studies, makes imiquimod a unique therapy for $\mathrm{AK}$ as well as for other cutaneous neoplasms.

\section{Abbreviations}

AK-actinic keratosis(ses), ANOVA-analysis of variance, BCC-basal cell carcinoma, DC-dendritic cells, IFN-interferon, IL-interleukin, IRF-interferon regulatory factor, 
NK-natural killer [cells], RT-PCR-Reverse Transcriptase Polymerase Chain Reaction, TLR-Toll like receptors

\section{Competing interests}

Abel Torres, MD, JD, has acted as a lecturer for $3 \mathrm{M}$ Pharmaceutical and has participated in 3M Pharmaceutical funded research. He also does consulting for $3 \mathrm{M}$ Pharmaceuticals.

RM, BJB, JJ, SR, and WB are employees of 3M Pharmaceuticals. JL and $\mathrm{HB}$ were employees of $3 \mathrm{M}$ Pharmaceuticals at the time of the study and manuscript writing.

\section{Authors' contributions}

AT, LS and MA conducted the clinical study. JL was the clinical coordinator. Gene expression analysis was performed at 3M Pharmaceuticals by WB, BB and JJ. All authors approved the manuscript.

\section{Additional material}

\section{Additional file 1 \\ Imiquimod regulated genes. This file summarizes fold change in expres- sion for 530 imiquimod regulated genes before and after treatment with imiquimod. Genes were selected on the basis of an ANOVA analysis com- paring pre-treatment AK expression values to expression values during imiquimod treatment or 4-weeks after treatment with imiquimod, with $P$ - values $<0.05$ \\ Click here for file \\ [http://www.biomedcentral.com/content/supplementary/1479- 5876-5-7-S1.doc]}

\section{Additional file 2}

Comparison of differential expression as measured by Affymetrix gene array and real time RT-PCR. This file summarizes a comparison of differential gene expression as measured by Affymetrix gene chip analysis and real time RT-PCR using low density TaqMan arrays. Expression changes for several toll-like receptors and other selected genes before and after treatment with imiquimod are reported.

Click here for file

[http://www.biomedcentral.com/content/supplementary/14795876-5-7-S2.doc]

\section{Additional file 3}

Imiquimod-induced genes with immune response gene ontology category and/or known to be IFN $\alpha / \beta$-inducible. This file reports on expression changes before and after treatment with imiquimod, for selected genes with gene ontology category of immune response and (or) are know to be inducible by type 1 interferons.

Click here for file

[http://www.biomedcentral.com/content/supplementary/14795876-5-7-S3.doc]

\section{Acknowledgements}

We thank Rhonda Dick for helping with manuscript preparation, and Dr. Mark Tomai for valuable criticism of the manuscript. Both are employees of 3 M Pharmaceuticals.

\section{References}

I. Callen JP, Bickers DR, Moy RL: Actinic keratosis. J Am Acad Dermatol 1997, 36:650-653.

2. Schwartz RA: The actinic keratosis: a perspective and update. Dermatol Surg 1997, 23:1009-1019.

3. Marks R, Rennie G, Selwood T: The relationship of basal cell carcinomas and squamous cell carcinomas to solar keratosis. Arch Dermatol 1988, 124: 1039-1042.

4. Nghiem DX, Kazimi N, Mitchell DL, Vink AA, Ananthaswamy HN, Kripke ML, Ullric : Mechanisms underlying the suppression of established immune responses by ultraviolet radiation. J Invest Dermatol 2002, 11 9:600-608.

5. Yantsos VA, Conrad N, Zabawski E, Cockerell CJ: Incipient intraepidermal cutaneous squamous cell carcinoma: A proposal for reclassifying and grading solar (actinic) keratosis. Semin Cutan Med Surg 1999, 18(1):3-14.

6. Glogau RG: The risk of progression to invasive disease. J Am Acad Dermatol 2000, 42(I Pt2):23-24.

7. Silapunt S, Goldberg LH, Alam M: Topical and light-based treatments for actinic keratosis. Semin Cutan Med Surg 2003, 22(3): $162-170$

8. Fu W, Cockerell Cl: The actinic (solar) keratosis: a 2 I st-century perspective. Arch Dermatol 2003, I39(1):66-70.

9. Takeda K, Akira S: Microbial recognition by Toll-like receptors. J Dermatol Sci 2004, 34:73-82.

10. Pasare $C$, Medzhitov $R: \mathbf{t}$ Toll-like receptors linking innate and adaptive immunity. Microbes Infect 2004, 6: 1382-1387.

II. Hornung V, Rothenfusser S, Britsch S, Krug A, Jahrsdorfer B, Giese T, Endres S, Hartmann G: Quantitative expression of toll-like receptor I-10 mRNA in cellular subsets of human peripheral blood mononuclear cells and sensitivity to CpG oligodeoxynucleotides. J Immunol 2002, I 68(9):453I-4537.

12. Kollisch G, Kalali BN, Voelcker V, Wallich R, Behrendt H, Ring J, Bauer $S$, Jakob T, Mempel M, Ollert M: Various members of the Toll-like receptor family contribute to the innate immune response of human epidermal keratinocytes. Immunology 2005, II4(4):53I-54I.

13. Mclnturff JE, Modlin RL, Kim J: The role of toll-like receptors in the pathogenesis and treatment of dermatological disease. Invest Dermatol 2005, I 25(I): I-8.

14. Hemmi H, Kaisho T, Takeuchi O, Sato S, Sanjo H, Hoshino K, Horiuchi T, Tomizawa H, Takeda K, Akira S: Small anti-viral compounds activate immune cells via the TLR7 MyD88-dependent signaling pathway. Nat Immunol 2002, 3:196-200.

15. Gibson SJ, Lindh JM, Riter TR, Gleason RM, Rogers LM, Fuller AE, Oesterich JL, Gorden KB, Qiu X, McKane SW, Noelle RJ, Miller RL, Kedl RM, Fitzgerald-Bocarsly P, Tomai MA, Vasilakos JP: Plasmacytoid dendritic cells produce cytokines and mature in response to the TLR7 agonists, imiquimod and resiquimod. Cell Immunol 2002, 21 8:74-86.

16. Beutner KR, Tyring SK, Trofatter KF Jr, Douglas JM Jr, Spruance $S$, Owens ML, Fox TL, Hougham AJ, Schmitt KA: Imiquimod, a patient-applied immune-response modifier for treatment of external genital warts. Antimicrob Agents Chemother 1998, 42(4):789-794.

17. Szeimies RM, Gerritsen MJ, Gupta G, Ortonne JP, Serresi S, Bichel J, Lee JH, Fox TL, Alomar A: Imiquimod 5\% cream for the treatment of actinic keratosis: results from a phase III, randomized, double-blind, vehicle-controlled, clinical trial with histology. J Am Acad Dermatol 2004, 5 I (4):547-555.

18. Geisse JK, Rich P, Pandya A, Gross K, Andres K, Ginkel A, Owens M: Imiquimod $5 \%$ cream for the treatment of superficial basal cell carcinoma: a double-blind, randomized, vehicle-controlled study. J Am Acad Dermatol 2002, 47(3):390-8.

19. Urosevic M, Maier T, Benninghoff B, Slade H, Burg G, Dummer R: Mechanisms underlying imiquimod-induced regression of basal cell carcinoma in vivo. Arch Dermatol 2003, I39: | 325-1332.

20. Barnetson RStC, Stachell A, Zhuang L, Slade HB, Halliday GM: Imiquimod induced regression of clinically diagnosed superficial basal cell carcinoma is associated with early infiltration by CD4 T cells and dendritic cells. Clin Exp Dermatol 2004, 29:639-643.

21. Miller RL, Gerster JF, Owens ML, Slade HB, Tomai MA: Imiquimod applied topically: A novel immune response modifier and a new class of drug. Int J Immunopharmacol 1999, 21:1-14.

22. Lysa $B$, Tartler $U$, Wolf $R$, Arenberger $P$, Benninghoff $B$, Ruzicka $T$, Hengge UR, Walz M: Gene expression in actinic keratosis: Pharmacological modulation by imiquimod. $\mathrm{Br}$ J Dermatol 2004 , I5 I(6): II50-1159.

23. Arany I, Tyring SK, Stanley MA, Tomai MA, Miller RL, Smith MH, McDermott DJ, Slade HB: Enhancement of the innate and cellu- 
lar immune response in patients with genital warts treated with topical imiquimod cream 5\%. Antiviral Res 1999, 43:55-63.

24. Bernstein DI, Miller RL, Harrison CJ: Adjuvant effects of imiquimod on a herpes simplex virus type 2 glycoprotein vaccine in guinea pigs. J Infect Dis 1993, I67(3):731-735

25. Bernstein DI, Harrison CJ, Tepe ER, Shahwan A, Miller R: Effect of imiquimod as an adjuvant for immunotherapy of genital HSV in guinea-pigs. Vaccine 1995, I 3(I):72-76.

26. Vasilakos JP, Smith RM, Gibson SJ, Lindh JM, Pederson LK, Reiter MI, Smith $\mathrm{MH}$, Tomai MA: Adjuvant activities of immune response modifier R-848: Comparison with CpG ODN. Cell Immunol 2000, 204:64-74.

27. Nair S, McLaughlin C, Weizer A, Su Z, Boczkowski D, Dannull J Vieweg J, Gilboa E: Injection of immature dendritic cells into adjuvant-treated skin obviates the need for ex vivo maturation. I Immunol 2003, I 7 I ( I I ):6275-6282.

28. Affymetrix Inc: Gene chip expression analysis technical manual. 2003.

29. Schindler $\mathrm{H}$, Wiese A, Auer J, Burtscher H: cRNA target preparation for microarrays: Comparison of gene expression profiles generated with different amplification procedures. Anal Biochem 2005, 344(I):92-101.

30. Klur S, Toy K, Williams MP, Certa U: Evaluation of procedures for amplification of small-size samples for hybridization on microarrays. Genomics 2004, 83(3):508-5I7.

31. Abruzzo LV, Lee KY, Fuller A, Silverman A, Keating MJ, Medeiros LJ, Coombes KR: Validation of oligonucleotide microarray data using microfluidic low-density arrays: A new statistical method to normalize real-time RT-PCR data. Biotechniques 2005, 38(5):785-792.

32. [http://www.geneontology.org/]

33. Zeeberg BR, Feng W, Wang G, Wang MD, Fojo AT, Sunshine M, Narasimhan S, Kane DW, Reinhold WC, Lababidi S, Bussey KJ, Riss J, Barrett JC, Weinstein JN: GoMiner: a resource for biological interpretation of genomic and proteomic data. Genome Biol 2003, 4:R28.

34. Kawai T, Sato S, Ishii KJ, Coban C, Hemmi H, Yamamoto M, Terai K Matsuda M, Inoue J, Uematsu S, Takeuchi O, Akira S: Interferonalpha induction through Toll-like receptors involves a direct interaction of IRF7 with MyD88 and TRAF6. Nat Immunol 2004, 5(10): $1061-8$.

35. Miettinen M, Sareneva T, Julkunen I, Matikainen S: IFNs activate tolllike receptor gene expression in viral infections. Genes Immun 200I, 2(6):349-355

36. Zarember KA, Godowski PJ: Tissue expression of human Tolllike receptors and differential regulation of Toll-like receptor mRNAs in leukocytes in response to microbes, their products, and cytokines. J Immunol 2002, I 68(2):554-56I. Erratum in: J Immunol 169(2): I136.

37. Kokkinopoulos I, Jordan WJ, Ritter MA: Toll-like receptor mRNA expression patterns in human dendritic cells and monocytes. Mol Immunol 2005, 42(8):957-968.

38. Siren J, Pirhonen J, Julkunen I, Matikainen S: IFN-alpha regulates TLR-dependent gene expression of IFN-alpha, IFN-beta, IL 28, and IL-29. J Immunol 2005, I 74(4): I932-1937.

39. Osterlund P, Veckman V, Siren J, Klucher KM, Hiscott J, Matikainen S, Julkunen I: Gene expression and antiviral activity of alpha/beta interferons and interleukin-29 in virus-infected human myeloid dendritic cells. J Virol 2005, 79(1 5):9608-9617.

40. Yoneyama M, Kikuchi M, Natsukawa T, Shinobu N, Imaizumi T, Miyagishi M, Taira K, Akira S, Fujita T: The RNA helicase RIG-I has an essential function in double-stranded RNA-induced innate antiviral responses. Nat Immunol 2004, 5(7):730-737.

4I. Yoneyama M, Kikuchi M, Matsumoto K, Imaizumi T, Miyagishi M, Taira K, Foy E, Loo YM, Gale M Jr, Akira S, Yonehara S, Kato A, Fujita T: Shared and unique functions of the $D E x D / H-B o x$ helicases RIG-I, MDA5, and LGP2 in antiviral innate immunity. J Immunol 2005, I 75(5):285I-2858.

42. Kawai T, Takahashi K, Sato S, Coban C, Kumar H, Kato H, Ishii KJ Takeuchi O, Akira S: IPS-I, an adaptor triggering RIG-I- and Mda5-mediated type I interferon induction. Nat Immunol 2005 6(10):981-988.

43. Taylor MW, Grosse WM, Schaley JE, Sanda C, Wu X, Chien SC, Smith F, Wu TG, Stephens M, Ferris MW, McClintick JN, Jerome RE, Edenberg HJ: Global effect of PEG-IFN-alpha and ribavirin on gene expression in PBMC in vitro. J Interferon Cytokine Res 2004 24(2): $107-118$

44. Nagorsen D, Deola S, Smith K, Wang E, Monsurro V, Zanovello P, Marincola FM, Panelli MC: Polarized monocyte response to cytokine stimulation. Genome Biol 2005, 6(2):RI5.

45. Kang DC, Gopalkrishnan RV, Wu Q, Jankowsky E, Pyle AM, Fisher PB: MDA-5 An interferon-inducible putative RNA helicase with double-stranded RNA-dependent ATPase activity and melanoma growth-suppressive properties. Proc Natl Acad Sci USA 2002, 99(2):637-642

46. Gorden KB, Gorski KS, Gibson SJ, KedI RM, Kieper WC, Qiu X, Tomai MA, Alkan SS, Vasilakos JP: Synthetic TLR agonists reveal functional differences between human TLR7 and TLR8. I Immunol 2005, I 74(3): I 259-I268

47. Khabar KS, Al-Haj L, Al-Zoghaibi F, Marie M, Dhalla M, Polyak SJ, Williams BR: Expressed gene clusters associated with cellular sensitivity and resistance towards anti-viral and anti-proliferative actions of interferon. J Mol Biol 2004, 342(3):833-846.

48. Der SD, Zhou A, Williams BR, Silverman RH: Identification of genes differentially regulated by interferon alpha, beta, or gamma using oligonucleotide arrays. Proc Natl Acad Sci USA 1998, 95(26): I5623-| 5628

49. Leaman DW, Chawla-Sarkar M, Jacobs B, Vyas K, Sun Y, Ozdemir A Yi T, Williams BR, Borden EC: Novel growth and death related interferon-stimulated genes (ISGs) in melanoma: Greater potency of IFN-beta compared with IFN-alpha2. I Interferon Cytokine Res 2003, 23( I 2):745-756.

50. Sarkar SN, Sen GC: Novel functions of proteins encoded by viral stress-inducible genes. Pharmacol Ther 2004, I 03(3):245-259.

51. Stroncek DF, Basil C, Nagorsen D, Deola S, Arico E, Smith K, Wang E, Marincola FM, Panelli MC: Delayed polarization of mononuclear phagocyte transcriptional program by type I interferon isoforms. J Transl Med 2005, 3:24.

52. Gordien E, Rosmorduc O, Peltekian C, Garreau F, Brechot C, Kremsdorf D: Inhibition of hepatitis B virus replication by the interferon-inducible MxA protein. J Virol 200I, 75:2684-269l.

53. Sheehy AM, Gaddis NC, Choi JD, Malim MH: Isolation of a human gene that inhibits HIV-I infection and is suppressed by the viral Vif protein. Nature 2002, 4I 8(6898):646-650.

54. Chin KC, Cresswell P: Viperin (cig5), an IFN-inducible antiviral protein directly induced by human cytomegalovirus. Proc Nat Acad Sci U S A 2001, 98(26): 15125-15130.

55. Castelli JC, Hassel BA, Maran A, Paranjape J, Hewitt JA, Li XL, Hsu YT, Silverman $\mathrm{RH}$, Youle $\mathrm{RJ}$ : The role of $2^{2}-5^{\prime}$ oligoadenylate-activated ribonuclease $L$ in apoptosis. Cell Death Differ I 998:3 I3-320.

56. de Veer MJ, Holko M, Frevel M, Walker E, Der S, Paranjape JM, Silverman RH, Williams BR: Functional classification of interferonstimulated genes identified using microarrays. J Leukoc Biol 2001, 69:912-920.

57. Papageorgiou A, Lashinger L, Millikan R, Grossman HB, Benedict W Dinney CP, McConkey DJ: Role of tumor necrosis factor-related apoptosis-inducing ligand in interferon-induced apoptosis in human bladder cancer cells. Cancer Res 2004, 64(24):8973-8979.

58. Keyser J, Schultz J, Ladell K, Elzaouk L, Heinzerling L, Pavlovic J, Moelling K: IP-IO-encoding plasmid DNA therapy exhibits antitumor and antimetastatic efficiency. Exp Dermatol 2004 I3(6):380.

59. Li S, Wilkinson M, Xia X, David M, Xu L, Purkel-Sutton A, Bhardwaj A: Induction of IFN-regulated factors and antitumoral surveillance by transfected placebo plasmid DNA. Mol Ther 2005 , II(I): I12-119.

60. Helbig KJ, Lau DT, Semendric L, Harley HA, Beard MR: Analysis of ISG expression in chronic hepatitis $\mathbf{C}$ identifies viperin as a potential antiviral effector. Hepatology 2005, 42(3):702-7I0.

61. Takaku T, Ohyashiki JH, Zhang Y, Ohyashiki K: Estimating immunoregulatory gene networks in human herpesvirus type 6infected $\mathbf{T}$ cells. Biochem Biophys Res Commun 2005 336(2):469-477.

62. Kim E], Park JI, Nelkin BD: IFII6 is an essential mediator of growth inhibition, but not differentiation, induced by the leukemia inhibitory factor/JAK/STAT pathway in medullary thyroid carcinoma cells. I Biol Chem 2005, 280(6):49|3-4920.

63. Ludlow LE, Johnstone RW, Clarke CJ: The HIN-200 family: More than interferon-inducible genes? Exp Cell Res 2005, 308(I): I- I 7 .

64. Chen GG, Lai PB, Ho RL, Chan PK, Xu H, Wong J, Lau WY: Reduction of double-stranded RNA-activated protein kinase in hepatocellular carcinoma associated with hepatitis B virus. Med Virol 2004, 73(2): 187-194.

65. Keefe D, Shi L, Feske S, Massol R, Navarro F, Kirchhausen T, Lieberman J: Perforin triggers a plasma membrane-repair response that facilitates CTL induction of apoptosis. Immunity 2005, 23(3):249-262

66. Wenzel J, Uerlich M, Haller O, Bieber T, Tueting T: Enhanced type $I$ interferon signaling and recruitment of chemokine receptor CXCR3-expressing lymphocytes into the skin following treatment with the TLR7-agonist imiquimod. I Cutan Pathol 2005 , 32(4):257-262

67. Urosevic M, Oberholzer PA, Maier T, Hafner J, Laine E, Slade H, Benninghoff $B$, Burg G, Dummer R: Imiquimod treatment induces 
expression of opioid growth factor receptor: A novel tumor antigen induced by interferon-alpha? Clin Cancer Res 2004, I 0( I5):4959-4970.

68. Korman N, Moy R, Ling M, Matheson R, Smith S, McKane S, Lee JH: Dosing with $5 \%$ imiquimod cream 3 times per week for the treatment of actinic keratosis: Results of two phase 3, randomized, double-blind, parallel-group, placebo-controlled trials. Arch Dermatol 2005, I 4 I (4):467-473.

69. Urosevic M, Dummer R, Conrad C, Beyeler M, Laine E, Burg G, Gilliet $M$ : Disease-independent skin recruitment and activation of plasmacytoid predendritic cells following imiquimod treatment. I Natl Cancer Inst 2005, 97( I 5): I | 43-I I53.

70. Matsumoto M, Tanaka T, Kaisho T, Sanjo H, Copeland NG, Gilbert DJ, Jenkins NA, Akira S: A novel LPS-inducible C-type lectin is a transcriptional target of NF-IL6 in macrophages. I Immunol 1999, 163:5039-5048.

7I. Walker MG: Z39lg is co-expressed with activated macrophage genes. Biochim Biophys Acta 2002, I 574(3):387-390.

72. Ooi T, Barnetson RS, Zhuang L, McKane S, Lee JH, Slade HB, Halliday GM: Imiquimod-induced regression of actinic keratosis is associated with infiltration by $T$ lymphocytes and dendritic cells: a randomized controlled trial. $\mathrm{Br} J$ Dermatol 2006, I 54:72-78.

73. Michalopoulos $\mathrm{P}$, Yawalkar N, Bronnimann $M$, Kappeler A, Braathen LR: Characterization of the cellular infiltrate during successful topical treatment of lentigo maligna with imiquimod. $\mathrm{Br} J \mathrm{Der}$ matol 2004, I 5 I (4):903-906.

74. Wolf IH, Cerroni L, Kodama K, Kerl H: Treatment of lentigo maligna (melanoma in situ) with the immune response modifier imiquimod. Arch Dermatol 2005, I 4 I (4):5 I 0-5 I 4.

75. Bates EE, Fournier N, Garcia E, Valladeau J, Durand I, Pin J], Zurawski SM, Patel S, Abrams JS, Lebecque S, Garrone P, Saeland S: APCs express DCIR, a novel C-type lectin surface receptor containing an immunoreceptor tyrosine-based inhibitory motif. J Immunol 1999, 163(4):1973-1983.

76. Ju XS, Hacker C, Scherer B, Redecke V, Berger T, Schuler G, Wagner $H$, Lipford GB, Zenke M: Immunoglobulin-like transcripts ILT2, ILT3 and ILT7 are expressed by human dendritic cells and down-regulated following activation. Gene 2004, 33I:159-164.

77. Rissoan MC, Duhen T, Bridon JM, Bendriss-Vermare N, Peronne C, de Saint Vis B, Briere F, Bates EE: Subtractive hybridization reveals the expression of immunoglobulinlike transcript 7, Eph-BI, granzyme $B$, and 3 novel transcripts in human plasmacytoid dendritic cells. Blood 2002, 100:3295-3303.

78. Palamara F, Meindl S, Holcmann M, Luhrs P, Stingl G, Sibilia M: Identification and characterization of pDC-like cells in normal mouse skin and melanomas treated with imiquimod. J Immunol 2004, I 73(5):305I-306I.

79. Peiser M, Grutzkau A, Wanner R, Kolde G: CDIa and CDIc cell sorting yields a homogeneous population of immature human Langerhans cells. J Immunol Methods 2003, 279(I2): $41-53$

80. Darmochwal-Kolarz D, Rolinski J, Buczkowski J, Tabarkiewicz J, Leszczynska-Gorzelak B, Zych I, Oleszczuk J: CDI c(+) immature myeloid dendritic cells are predominant in cord blood of healthy neonates. Immunol Lett 2004, 9 I(I):71-74.

81. Suzuki H, Wang B, Shivji GM, Toto P, Amerio P, Tomai MA, Miller RL Sauder DN: Imiquimod, a topical immune response modifer, induces migration of Langerhans cells. J Investig Dermatol 2000, I | 4: I35-|4|.

82. Verneris MR, Karami M, Baker J, Jayaswal A, Negrin RS: Role of NKG2D signaling in the cytotoxicity of activated and expanded CD8+ T cells. Blood 2004, I 03(8):3065-3072.

83. Pisegna S, Zingoni A, Pirozzi G, Cinque B, Cifone MG, Morrone S, Piccoli M, Frati L, Palmieri G, Santoni A: Src-dependent Syk activation controls CD69-mediated signaling and function on human NK cells. J Immunol 2002, I 69:68-74.

84. Barber DF, Faure M, Long EO: LFA-I contributes an early signal for NK cell cytotoxicity. J Immunol 2004, I 73(6):3653-3659.

85. Anikeeva N, Somersalo K, Sims TN, Thomas VK, Dustin ML, Sykulev $Y$ : Distinct role of lymphocyte function-associated antigen-I in mediating effective cytolytic activity by cytotoxic $\mathbf{T}$ lymphocytes. Proc Natl Acad Sci USA 2005, I 02( I 8):6437-6442.

86. Cella M, Fujikawa K, Tassi I, Kim S, Latinis K, Nishi S, Yokoyama W, Colonna M, Swat W: Differential requirements for Vav proteins in DAPI 0 - and ITAM-mediated NK cell cytotoxicity. J Exp Med 2004, 200(6):817-823.

87. Groh V, Rhinehart R, Randolph-Habecker J, Topp MS, Riddell SR, Spies $\mathrm{T}$ : Costimulation of CD8 $\alpha \beta$ T cells by NKG2D via engagement by MIC induced on virus-infected cells. Nat Immunol 2001 , 2(3):255-260.
88. Jinushi M, Takehara T, Kanto T, Tatsumi T, Groh V, Spies T, Miyagi T, Suzuki T, Sasaki Y, Hayashi NT: Critical role of MHC class Irelated chain A and $B$ expression on IFNA $\alpha$-stimulated dendritic cells in NK cell activation: Impairment in chronic hepatitis C virus infection. I Immunol 2003, I 70: I249-56.

89. Waterhouse NJ, Clarke CJ, Sedelies KA, Teng MW, Trapani JA: Cytotoxic lymphocytes; Instigators of dramatic target cell death. Biochem Pharmacol 2004, 68(6): 1033-1040.

90. Wowk ME, Trapani JA: Cytotoxic activity of the lymphocyte toxin granzyme B. Microbes Infect 2004, 6(8):752-758.

91. Medley QG, Kedersha N, O'Brien S, Tian Q, Schlossman SF, Streuli M, Anderson P: Characterization of GMP-I7, a granule membrane protein that moves to the plasma membrane of natural killer cells following target cell recognition. Proc Natl Acad Sci U S A 1996, 93(2):685-689.

92. Smyth MJ, Cretney E, Kelly JM, Westwood JA, Street SE, Yagita H, Takeda K, van Dommelen SL, Degli-Esposti MA, Hayakawa Y: Activation of NK cell cytotoxicity. Mol Immunol 2005, 42:50I-5 I0.

93. Ashton-Rickardt PG: The granule pathway of programmed cell death. Crit Rev Immunol 2005, 25(3): 161-182

94. Denny MF, Patai B, Straus DB: Differential T-cell antigen receptor signaling mediated by the Src family kinases Lck and Fyn. Mol Cell Biol 2000, 20(4): |426-|435.

95. Kuhne MR, Lin J, Yablonski D, Mollenauer MN, Ehrlich LI, Huppa J, Davis MM, Weiss A: Linker for activation of T cells, zeta-associated protein-70, and Src homology 2 domain-containing leukocyte protein-76 are required for TCR-induced microtubule-organizing center polarization. J Immunol 2003 , | 7 |:860-866.

96. Wherry EJ, Ahmed R: Memory CD8 T-cell differentiation during viral infection. I Virol 2004, 78( I I):5535-5545.

97. Fuller MJ, Hildeman DA, Sabbaj S, Gaddis DE, Tebo AE, Shang L, Goepfert PA, Zajac AJ: Cutting edge: Emergence of CDI 27high functionally competent memory $\mathbf{T}$ cells is compromised by high viral loads and inadequate $\mathbf{T}$ cell help. I Immunol 2005, I 74( ( 0):5926-5930.

98. Rodriguez MW, Paquet AC, Yang YH, Erle DJ: Differential gene expression by integrin beta $7+$ and beta 7-memory $T$ helper cells. BMC Immunol 2004, 5: I 3.

99. Smith KJ, Hamza S, Skelton H: Topical imidazoquinoline therapy of cutaneous squamous cell carcinoma polarizes lymphoid and monocyte/macrophage populations to a ThI and $M I$ cytokine pattern. Clin Exp Dermatol 2004, 29(5):505-5I 2.

100. Bernstein DI, Harrison CJ, Tomai MA, Miller RL: Daily or weekly therapy with resiquimod (R-848) reduces genital recurrences in herpes simplex virus-infected guinea pigs during and after treatment. J Infect Dis 2001, I 83(6):844-849.

101. Stockfleth E, Christophers E, Benninghoff B, Sterry W: Low incidence of new actinic keratosis after topical $5 \%$ imiquimod cream treatment: A long-term follow-up study. Arch Dermatol 2004, I 40( I 2): I542.

102. Mohty M, Vialle-Castellano A, Nunes JA, Isnardon D, Olive D, Gaugler $B$ : IFN-alpha skews monocyte differentiation into Toll-like receptor 7-expressing dendritic cells with potent functional activities. J Immunol 2003, I 7 I(7):3385-3393.

Publish with Bio Med Central and every scientist can read your work free of charge

"BioMed Central will be the most significant development for disseminating the results of biomedical research in our lifetime. "

Sir Paul Nurse, Cancer Research UK

Your research papers will be:

- available free of charge to the entire biomedical community

- peer reviewed and published immediately upon acceptance

- cited in PubMed and archived on PubMed Central

- yours - you keep the copyright
BioMedcentral 